Review

\title{
Developments in electrode materials and electrolytes for aluminium-air batteries
}

\author{
D.R. Egan ${ }^{\text {a }}$, C. Ponce de León ${ }^{\text {a,* }}$, R.J.K. Wood ${ }^{\text {b }}$, R.L. Jones ${ }^{c}$, K.R. Stokes ${ }^{\text {b,c }}$, F.C. Walsh ${ }^{\text {a,b }}$ \\ ${ }^{a}$ Electrochemical Engineering Laboratory, Energy Technology Research Group, School of Engineering Sciences, University of Southampton, SO17 1BJ, UK \\ ${ }^{\mathrm{b}}$ National Centre for Advanced Tribology at Southampton School of Engineering Sciences, University of Southampton, SO17 1BJ, UK \\ ${ }^{\mathrm{c}}$ Dstl, Physical Sciences Department, Porton Down, Salisbury, Wiltshire SP4 OJQ UK
}

\section{H I G H L I G H T S}

- Discussion of the rationale to choose a suitable alloy for Al-air battery.

- Effect of the properties and preparation route to enhance the oxidation of Al.

- Effect of the inhibitors on the anode oxidation in the alkaline electrolyte.

- Comparison of the performance of high-activity oxygen reduction electrodes.

\section{A $\quad$ R $\quad$ T I I C L L E I I N F}

\section{Article history:}

Received 20 November 2012

Received in revised form

19 January 2013

Accepted 22 January 2013

Available online 15 March 2013

\section{Keywords:}

Aluminium anode

Corrosion

Equilibrium redox potential

Inhibitors

Ionic liquid

Oxygen reduction

\begin{abstract}
A B S T R A C T
Aluminium-air cells are high-energy density $\left(<400 \mathrm{~W} \mathrm{~h} \mathrm{~kg}^{-1}\right)$ primary batteries developed in the $1960 \mathrm{~s}$. This review shows the influence of the materials, including: aluminium alloy, oxygen reduction catalyst and electrolyte type, in the battery performance. Two issues are considered: (a) the parasitic corrosion of aluminium at open-circuit potential and under discharge, due to the reduction of water on the anode and (b) the formation of a passive hydroxide layer on aluminium, which inhibits dissolution and shifts its potential to positive values. To overcome these two issues, super-pure (99.999 wt\%) aluminium alloyed with traces of $\mathrm{Mg}, \mathrm{Sn}$, In and Ga are used to inhibit corrosion or to break down the passive hydroxide layer. Since high-purity aluminium alloys are expensive, an alternative approach is to add inhibitors or additives directly into the electrolyte. The effectiveness of binary and ternary alloys and the addition of different electrolyte additives are evaluated. Novel methods to overcome the self-corrosion problem include using anionic membranes and gel electrolytes or alternative solvents, such as alcohols or ionic liquids, to replace aqueous solutions. The air cathode is also considered and future opportunities and directions for the development of aluminium-air cells are highlighted.
\end{abstract}

(c) 2013 Elsevier B.V. All rights reserved.

\section{Introduction}

Current research across the breath of energy storage technologies is focused on reducing system weight to improve energy density [1]. The lightness of aluminium energy storage technologies, such as $\mathrm{Al}-\mathrm{H}_{2} \mathrm{O}_{2}$ or $\mathrm{Al}-\mathrm{S}$ systems, has meant that they have received renewed interest for a variety of applications [2,3]. Among these systems is the aluminium-air battery with a practical specific energy density of $400 \mathrm{~W} \mathrm{~h} \mathrm{~kg} \mathrm{~W}^{-1}$ surpassing that of lithium-ion batteries [4-7]. The aluminium-air cell (Fig. 1) is a primary metal-air battery with an aluminium anode and an air-breathing cathode in contact with an aqueous electrolyte, typically sodium hydroxide, potassium hydroxide or sodium chloride [8]. The

\footnotetext{
* Corresponding author. Tel.: +44 (0)23 8059 8931; fax: +44 (0)23 80597051.

E-mail address: capla@soton.ac.uk (C. Ponce de León).
}

geological abundance of aluminium metal, a recyclable reaction product of $\mathrm{Al}(\mathrm{OH})_{3}$, and rapid mechanical rechargeability are additional benefits of this battery along with a very negative thermodynamic electrode potential for aluminium in alkaline solutions of ca. $-2.4 \mathrm{~V}$ vs. $\mathrm{Hg} / \mathrm{HgO}$, as indicated by the Pourbaix Diagram [9].

In practice, the open-circuit potential of aluminium is more positive at $-1.66 \mathrm{~V} v s$. $\mathrm{Hg} / \mathrm{HgO}$ [10], due to the competition between the numerous electrode processes that take place on the aluminium surface [11]: (i) formation and/or dissolution of an initial $\mathrm{Al}_{2} \mathrm{O}_{3}$ and subsequent $\mathrm{Al}(\mathrm{OH})_{3}$ layer, (ii) three-electron charge transfer yielding $\mathrm{Al}^{\mathrm{III}}$ species, (iii) formation of corrosion products, $\mathrm{Al}(\mathrm{OH})_{4}^{-}$and $\mathrm{Al}(\mathrm{OH})_{3}$, as well as (iv) a parasitic corrosion reaction involving the reduction of water at localised cathodic centres on the aluminium surface, which releases hydrogen [12]. This self-corrosion at open-circuit prevents the storage of wet aluminium-air batteries and reduces their 


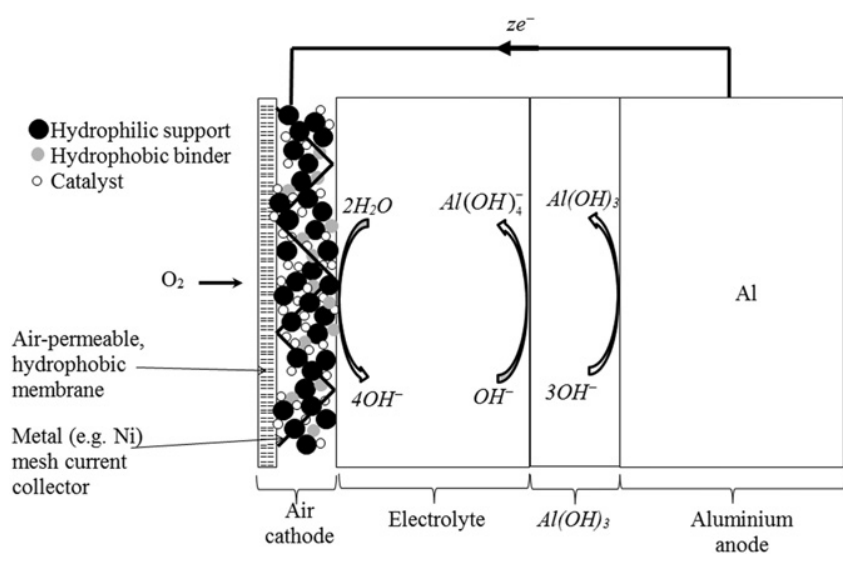

Fig. 1. Illustration of the structure of an aluminium-air battery using a 3-layer gas diffusion electrode and, in this case, pure aluminium as anode with its passive hydroxide layer

discharge efficiency. Research has focused on ways to enhance the aluminium oxidation rate while inhibiting the self-corrosion reaction.

This literature on aluminium-air batteries spans fifty years (Fig. 2), some of which is accessible as publications and patents while others, such as internal company reports, are more restricted. The extent to which this large body of work has been reviewed is variable. For example some surveys covering the variety of aluminium energy storage systems devote a subsection to the aluminium-air battery electrochemistry $[2,3]$. Others focus solely on aluminium-air batteries and detail the advances made together with their developing applications [13-20], such as a power source for electric vehicles [21,22]. There are specialised reviews that examine aluminium corrosion mechanisms in saline solutions for the cathodic protection of marine structures [23] and under opencircuit conditions in alkaline solutions with relevance to nuclear engineering [24]. Currently, the rapid development of rechargeable metal-air cells such as the lithium-air and zinc-air ones has attracted considerable interest. The classical aluminium-air cell retains niche applications and continues to attract attention, however, since it is simple in design and robust, has none of the safety concerns raised by lithium-air and is environmentally sustainable due to the known resources of aluminium and the facility for recycling the metal.

In this review, experimental data from the literature is critically compared with the aim of examining how different aluminium alloys and alkaline electrolytes affect the performance of the aluminium-air battery by reducing the parasitic corrosion and overcoming the passive hydroxide layer, often referred to as 'activating' the aluminium. Research has focused on alloying pure aluminium with certain elements to achieve such activation. The rationale behind the choice of alloying elements, their concentration and the mechanisms by which they activate the aluminium to yield higher anodic currents is discussed. Given that the maximum electrical energy cycle efficiency of an aluminium energy storage system is $22 \%$ [2], one lower cost solution involves using commercial grade aluminium and adding inhibitors to the electrolyte. The effectiveness of these inhibitors, singly and in combination, and in different concentrations is reviewed. The air cathode of the battery is concisely discussed, with the essential factors influencing its performance being summarised but the review does not consider cell design in detail. Finally, future developments in aluminium-air batteries are discussed.

\section{Corrosion of $99.999 \mathrm{wt} \%$ high-purity aluminium in alkaline solutions}

Aluminium-air batteries employing alkaline electrolytes are primary energy storage devices since electrodeposition of aluminium from alkaline solutions is not thermodynamically feasible due to its negative standard potential which will lead to hydrogen evolution at the negative electrode before any aluminium

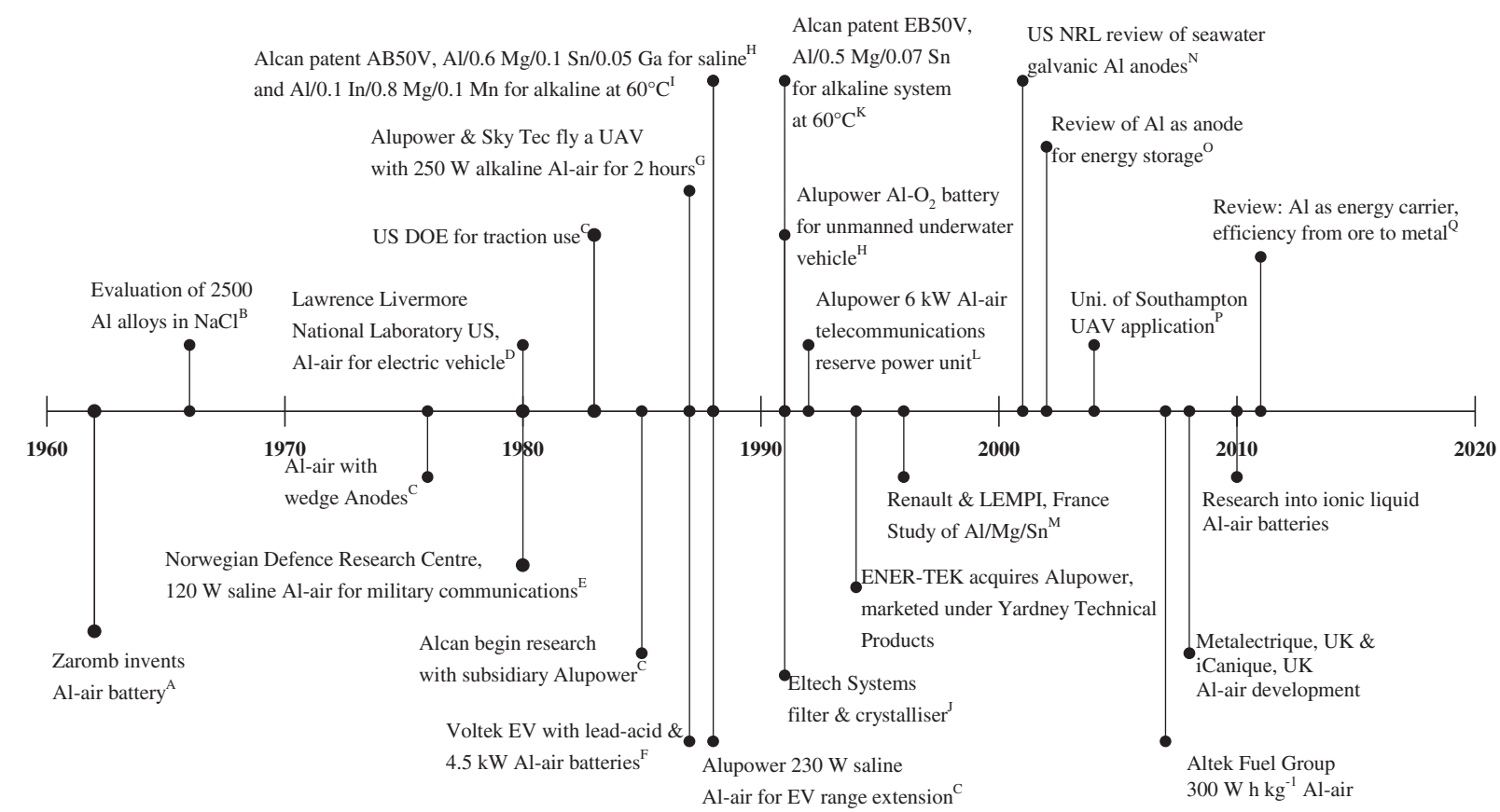

Fig. 2. Timeline of the history of the development of aluminium-air batteries. ${ }^{\mathrm{A}}[202],{ }^{\mathrm{B}}[203],{ }^{\mathrm{C}}[17],{ }^{\mathrm{D}}[204],{ }^{\mathrm{E}}[205],{ }^{\mathrm{F}}[206],{ }^{\mathrm{G}}[207,208],{ }^{\mathrm{H}}[13],{ }^{\mathrm{I}}[75],{ }^{\mathrm{J}}[209],{ }^{\mathrm{K}}[50],{ }^{\mathrm{L}}[210],{ }^{\mathrm{M}}[61],{ }^{\mathrm{N}}$ [23], $\mathrm{O}[3],{ }^{\mathrm{P}}[28,151],{ }^{\mathrm{Q}}[2]$. EV is electric vehicle; UAV is unmanned aerial vehicle. 
can be deposited $[25,26]$. Mechanically recharging is possible by replacing the aluminium anode after each discharge [27]. The ideal overall discharge reaction of the aluminium-air cell is:

$4 \mathrm{Al}+3 \mathrm{O}_{2}+6 \mathrm{H}_{2} \mathrm{O} \rightarrow 4 \mathrm{Al}(\mathrm{OH})_{3}$

$$
E_{\text {cell }}=2.7 \mathrm{~V}
$$

The positive electrode is an air or gas diffusion electrode, conventionally comprising a carbon-based structure which brings oxygen and the electrolyte into contact with a catalyst resulting in oxygen reduction [28]:

$$
\mathrm{O}_{2}+2 \mathrm{H}_{2} \mathrm{O}+4 \mathrm{e}^{-} \rightarrow 4 \mathrm{OH}^{-} \quad E_{c}=0.3 \mathrm{~V} \text { vs. } \mathrm{Hg} / \mathrm{HgO}
$$

At the negative electrode the overall anodic reaction involves the oxidation of aluminium to aluminate ions [29]

$$
\mathrm{Al}+4 \mathrm{OH}^{-} \rightarrow \mathrm{Al}(\mathrm{OH})_{4}^{-}+3 \mathrm{e}^{-} \quad E_{a}=-2.4 \mathrm{~V} \text { vs. } \mathrm{Hg} / \mathrm{HgO}
$$

In parallel with the oxidation of the aluminium, is a parasitic reaction involving the reduction of water resulting in hydrogen gas evolution:

$$
\mathrm{H}_{2} \mathrm{O}+\mathrm{e}^{-} \rightarrow 0.5 \mathrm{H}_{2}+\mathrm{OH}^{-} \quad E=-0.93 \mathrm{~V} \text { vs. } \mathrm{Hg} / \mathrm{HgO}
$$

Reactions (3) and (4) are competing reactions on the surface of aluminium when in contact with an alkaline electrolyte. The net current, $I$, that flows through the external circuit is the difference in magnitude of the dissolution of aluminium, $I_{d}$, and corrosion current, $I_{\text {cor }}$.

$I=I_{d}-I_{\text {cor }}$

The corrosion behaviour of aluminium and its alloys can be compared by evaluating the corrosion current at open-circuit potential and under discharge. Suitable methods are discussed in the next section.

\subsection{Evaluating the electrochemical behaviour of aluminium}

The most quantitative technique for evaluating the corrosion behaviour of aluminium involves measuring the corrosion current as a function of applied potential or discharge current $[10,11,30-$ 35]. The corrosion rate of aluminium alloys in alkaline solutions varies with time [36], which is particularly evident at the opencircuit potential for aluminium alloys when the changes in the rate of hydrogen evolution exactly mirror the changes in the open-circuit electrode potential with time [37]. Upon immersion, the open-circuit potential of aluminium alloys shifts to a very negative value of $-2.0 \mathrm{~V} v \mathrm{~s}$. $\mathrm{Hg} / \mathrm{HgO}$ due to the presence of aluminium hydrides $[38,39]$, and possibly hydrides of the alloying elements, creating a hydroxide-free surface and a high rate of hydrogen evolution [37]. Once the alloy surface becomes passivated by a hydroxide layer, its potential shifts more positively, which is accompanied by a reduction in the rate of hydrogen evolution.

The variable nature of the corrosion rate means that mass loss data, for example, recorded at the end of an experiment, would not give an accurate measure of the steady-state corrosion current. An in-situ technique would be preferred such as oxidising the evolved hydrogen on nickel foam [30] or on the platinum ring of a rotating ring-disc electrode [11]. Such techniques, however, have uncertainties as to whether all the evolved hydrogen is detected, particularly during periods of high hydrogen evolution.

The most accurate technique involves calculating the corrosion current from the volume of evolved hydrogen gas, collected during galvanostatic tests [10]. The corrosion current, $I_{c o r}$, is calculated from the volume of hydrogen using Eq. (6), derived from Faraday's laws of electrolysis and the Ideal gas law [40]:

$I_{c o r}=\frac{z F P V}{t R_{u} T}$

Using Faraday's law, the corrosion current density, $j_{c o r}$ is related to the corrosion rate $(C R)$, as follows

$C R=\frac{j_{c o r} M_{w}}{z F}$

where $z$ is the two electrons consumed to reduce water to hydrogen, $F$ is Faraday's constant, $M_{w}$ is the molar mass of aluminium, $27 \mathrm{~g} \mathrm{~mol}^{-1}, P$ is atmospheric pressure, $V$ is the volume of hydrogen evolved, $t$ is time for which hydrogen was collected, $R_{u}$ is the universal gas constant, $8.314 \mathrm{~J} \mathrm{~mol}^{-1} \mathrm{~K}^{-1}$ and $T$ is the temperature in Kelvin.

In this review, using corrosion currents reported in the literature, two parameters were used to evaluate the corrosion behaviour of the alloys: the open-circuit inhibition efficiency, $\varphi_{\text {inh }}$ and the discharge efficiency, $\varphi_{\text {dis }}$. The open-circuit inhibition efficiency indicates the percentage difference between the corrosion of the alloy and that of pure aluminium.

$\varphi_{\text {inh }}=\left(\frac{I_{c o r, p}-I_{c o r, a}}{I_{c o r, p}}\right) * 100$

where $I_{c o r, p}$ and $I_{c o r, a}$ are the corrosion currents for pure aluminium and the alloy at open-circuit. If an alloy has positive inhibition efficiency at open-circuit, then its corrosion current is lower than that of pure aluminium, i.e. $I_{c o r, a}<I_{c o r, p}$, which is desirable of a suitable anode material in an $\mathrm{Al}$-air battery. An alloy with negative inhibition efficiency indicates that its open-circuit corrosion current is worse than that of pure aluminium. The vector for evaluating the corrosion behaviour of the aluminium alloys under discharge is the discharge efficiency, $\varphi_{\text {dis }}$, which is the ratio of the discharge current, $I$, to the sum of discharge and corrosion current, $I_{\text {cor }}$ :

$\varphi_{\text {dis }}=\frac{I}{I+I_{\text {cor }}} * 100$

\subsection{Choice of electrolyte for aluminium-air cells}

The electrolyte used in aluminium-air cells is typically an aqueous alkaline solution such as sodium hydroxide or potassium hydroxide. Neutral saline electrolytes have also been used [27,28,41-47], because compared with caustic solutions they exhibit a lower open-circuit corrosion rate and pose a lower risk to health $[48,49]$. Carbonation of the alkaline electrolyte by carbon dioxide in the air can impede air access and cause mechanical damage to the gas diffusion electrode [3]. However the higher conductivity and $\mathrm{Al}(\mathrm{OH})_{3}$ solubility of alkaline solutions [27] allows high cell power $\left(175 \mathrm{~W} \mathrm{~kg}^{-1}\right)$ and energy densities $\left(400 \mathrm{~W} \mathrm{~h} \mathrm{~kg}^{-1}\right.$ ) to be attained compared to saline systems (30 W $\mathrm{kg}^{-1}$, $220 \mathrm{~W} \mathrm{~h} \mathrm{~kg}^{-1}$ ) [50]. This is attractive for high-power applications such as standby batteries together with propulsion of unmanned underwater vehicles and electric vehicles.

Some papers have reported using sulphuric acid as an electrolyte for aluminium-air cells, in which the theoretical cell potential differences are higher than in alkaline electrolytes and carbonation problems for the air electrode can be avoided [51,52]. However, aluminium is passivated by a relatively thick oxide layer in 
Table 1

The regions of thermodynamic stability for metals in $\mathrm{pH} 14$ alkaline electrolytes. Compiled from Pourbaix Diagrams [9], together with hydrogen overpotential vs. melting temperature data for various metals in $6 \mathrm{~mol} \mathrm{~L}^{-1} \mathrm{NaOH}$ solution at $25{ }^{\circ} \mathrm{C}$ [187,188]. $T_{m}$ is melting temperature and $\eta_{\mathrm{H}_{2}}$ is hydrogen overpotential.

\begin{tabular}{|c|c|c|c|c|c|c|c|}
\hline \multirow[t]{2}{*}{ Metal } & \multicolumn{4}{|c|}{ Region of stability in $\mathrm{pH} 14$ electrolyte } & \multirow{2}{*}{$\begin{array}{l}T_{m} / \\
{ }^{\circ} \mathrm{C}\end{array}$} & \multirow{2}{*}{$\begin{array}{l}\eta_{\mathrm{H}_{2}} / \\
\mathrm{V}\end{array}$} & \multirow{2}{*}{$\begin{array}{l}\text { Solubility } \\
\text { limit in } \mathrm{Al}\end{array}$} \\
\hline & $\begin{array}{l}\text { Reduc } \\
\text { vs. Hg }\end{array}$ & $\begin{array}{l}\text { species } \\
\mathrm{O} / \mathrm{V}\end{array}$ & $\begin{array}{l}\text { Oxidised } \\
\text { vs. } \mathrm{Hg} / \mathrm{Hg}\end{array}$ & & & & \\
\hline $\mathrm{Fe}$ & & & & -1.06 & 1540 & 0.41 & $\begin{array}{l}0.025 \% \\
\text { at } 600{ }^{\circ} \mathrm{C}\end{array}$ \\
\hline $\mathrm{Cu}$ & & & & -0.55 & 1080 & 0.59 & $\begin{array}{l}2.97 \% \\
\text { at } 600{ }^{\circ} \mathrm{C}\end{array}$ \\
\hline $\mathrm{Pb}$ & & & & -0.83 & 328 & 1.05 & $\begin{array}{l}0.15 \% \\
\text { at } 658{ }^{\circ} \mathrm{C}\end{array}$ \\
\hline $\mathrm{Bi}$ & $\mathrm{BiH}_{3}$ & -1.70 & $\mathrm{BiO}_{3}^{-}$ & -0.61 & 272 & 0.96 & $\begin{array}{l}<0.10 \% \\
\text { at } 657{ }^{\circ} \mathrm{C}\end{array}$ \\
\hline Cd & & & $\mathrm{HCdO}_{2}^{-}$ & -1.06 & 322 & 0.85 & $\begin{array}{l}0.25 \% \\
\text { at } 600{ }^{\circ} \mathrm{C}\end{array}$ \\
\hline $\mathrm{Sb}$ & $\mathrm{SbH}_{3}$ & -1.32 & $\mathrm{SbO}_{3}^{-}$ & -0.90 & 631 & 0.70 & $\begin{array}{l}<0.10 \% \\
\text { at } 657{ }^{\circ} \mathrm{C}\end{array}$ \\
\hline Sn & $\mathrm{SnH}_{4}$ & -2.05 & $\mathrm{SnO}_{3}^{2-}$ & -1.27 & 232 & 1.00 & $\begin{array}{l}0.10 \% \\
\text { at } 600{ }^{\circ} \mathrm{C}\end{array}$ \\
\hline In & & & & -1.15 & 157 & & $\begin{array}{l}0.13 \% \\
\text { at } 600{ }^{\circ} \mathrm{C}\end{array}$ \\
\hline $\mathrm{Ga}$ & & & $\mathrm{Ga}(\mathrm{OH})_{4}^{-}$ & -1.61 & 30 & & $\begin{array}{l}6.00 \% \\
\text { at } 600{ }^{\circ} \mathrm{C}\end{array}$ \\
\hline Zn & & & $\mathrm{ZnO}_{2}^{2-}$ & -1.61 & 420 & 1.10 & $\begin{array}{l}14.6 \% \\
\text { at } 600{ }^{\circ} \mathrm{C}\end{array}$ \\
\hline Mn & & & & -1.74 & 1250 & 0.76 & $\begin{array}{l}1.03 \% \\
\text { at } 600{ }^{\circ} \mathrm{C}\end{array}$ \\
\hline $\mathrm{Al}$ & & & $\mathrm{Al}(\mathrm{OH})_{4}^{-}$ & -2.48 & 657 & 0.47 & \\
\hline $\mathrm{Mg}$ & & & $\mathrm{Mg}(\mathrm{OH})_{2}$ & -2.79 & 650 & 1.47 & $\begin{array}{l}3.6 \% \\
\text { at } 600{ }^{\circ} \mathrm{C}\end{array}$ \\
\hline
\end{tabular}

concentrated sulphuric acid solutions [51], necessitating the addition of $\mathrm{Cl}^{-}$or $\mathrm{F}^{-}$ions to partially destroy the oxide through pitting [51,53], These ions adversely affect the air electrode by adsorption on the platinum catalyst diminishing the amount of platinum oxide that can be formed and increasing the overpotential for oxygen reduction [51,54]. Hence, this review will focus on alkaline solutions as electrolytes for aluminium-air batteries.

Preferred electrolytes for aluminium-air batteries are $4 \mathrm{~mol} \mathrm{dm}^{-3} \mathrm{NaOH}$ and $7 \mathrm{~mol} \mathrm{dm}{ }^{-3} \mathrm{KOH}$, which correspond to their peak electrolytic conductivities [32-34,50,55]. The purity of the electrolyte must be of analytical grade, as any electrolyte impurities such as $\mathrm{Fe}^{2+}$ ions would reduce on the aluminium surface creating preferential sites for hydrogen evolution, influencing the corrosion and electrode potential $[10,55]$. The peak electrolytic conductivity of potassium hydroxide at $0.7 \mathrm{~S} \mathrm{~cm}^{-1}$ [56], is superior to that of $4 \mathrm{~mol} \mathrm{dm}^{-3}$ sodium hydroxide $\left(0.39 \mathrm{~S} \mathrm{~cm}^{-1}\right)$ [55]. Also $\mathrm{KOH}$ shows superiority to $\mathrm{NaOH}$ solutions for oxygen reduction because of higher solubility for oxygen, higher oxygen diffusion coefficients and lower viscosity [57]. However KOH solution does not allow the recycling of alumina via the industrial Hall-Héroult process [3]. This would be important for mass-production of aluminium-air cells requiring the recycling of spent electrolytes [3].

The solubility limit of the reaction product, aluminate, is also higher in $7 \mathrm{~mol} \mathrm{dm}^{-3} \mathrm{KOH}$ at $6 \mathrm{~g}$ per $100 \mathrm{~g}$ of electrolyte compared to $4 \mathrm{~g}$ per $100 \mathrm{~g}$ of electrolyte for a $4 \mathrm{~mol} \mathrm{dm}^{-3} \mathrm{NaOH}$ solution $[58,59]$. This is an important consideration for aluminium-air batteries using static electrolytes, as when the saturation level for $\mathrm{Al}(\mathrm{OH})_{4}^{-}$is reached, it precipitates out as $\mathrm{Al}(\mathrm{OH})_{3}$ or the hydrargillite phase. The $\mathrm{Al}(\mathrm{OH})_{3}$ binds to water, reducing its availability for oxygen reduction at the cathode and blocks pores. The accumulation of the $\mathrm{Al}(\mathrm{OH})_{4}^{-}$in static electrolyte aluminium-air batteries results in a viscous gel layer, slowing the diffusion of $\mathrm{OH}^{-}$ions towards the $\mathrm{Al}$ surface and reducing the rate of aluminium dissolution [10]. In addition, the consumption of $\mathrm{OH}^{-}$ions to form
$\mathrm{Al}(\mathrm{OH})_{4}^{-}$lowers electrolyte conductivity allowing the hydroxide film to thicken impeding further dissolution [33]. Conductivity rises again once precipitation of $\mathrm{Al}(\mathrm{OH})_{3}$ liberates $\mathrm{OH}^{-}$ions.

To overcome these issues of fluctuating electrolyte conductivity and accumulation of $\mathrm{Al}(\mathrm{OH})_{3}$ at the electrodes, large-scale aluminium-air systems typically employ a circulating electrolyte pumped from an external tank. This prevents hydroxide build-up and cathode pore blocking [60], removes hydrogen bubbles from the aluminium surface [61] and allows integration of peripherals such as a heat exchanger or filter/crystalliser unit [15]. A heat exchanger helps to cool down the electrolyte, preventing it from boiling [62], while a crystalliser promotes the crystallisation of $\mathrm{Al}(\mathrm{OH})_{4}^{-}$into insoluble $\mathrm{Al}(\mathrm{OH})_{3}$, increasing the $\mathrm{OH}^{-}$ion concentration, via reaction (13). The subsequent rise in electrolytic conductivity helps to maintain a steady cell potential difference for a longer time, enhancing the energy density of the cell for a given electrolyte tank volume [63]. The initial fluctuations in electrolyte conductivity can be avoided by adding seed crystals of $\mathrm{Al}(\mathrm{OH})_{3}$, typically $1 \mu \mathrm{m}$ in size, to the electrolyte saturating it with aluminate. Aluminate ions formed during the oxidation of the aluminium anode would immediately precipitate to form aluminium hydroxide [64], which is filtered from the electrolyte $[3,17,28,65]$.

\subsection{Mechanism of super-pure aluminium corrosion in alkaline solutions}

In open atmosphere, the surface of aluminium is covered by a $4 \mathrm{~nm}$ thick oxide film of $\mathrm{Al}_{2} \mathrm{O}_{3}$ [66]. Upon initial immersion of $99.99 \mathrm{wt} \%$ aluminium in a $4 \mathrm{~mol} \mathrm{dm}{ }^{-3}$ sodium hydroxide solution, the $\mathrm{Al}_{2} \mathrm{O}_{3}$ layer is rapidly dissolved under a high rate of hydrogen evolution as a result of the alkalinisation of the electrode surface $[10,24]$.

At this point, the electrode potential at open-circuit is $-1.73 \mathrm{~V}$ vs. $\mathrm{Hg} / \mathrm{HgO}$ [67], which is a mixed electrode potential owing to the oxidation of aluminium, the reduction of water and the growth of aluminium hydroxide layer. The film-free surface then undergoes dissolution via a series of 3 one-electron steps and hydroxide addition, leading to the final tri-hydroxide, $\mathrm{Al}(\mathrm{OH})_{3}[10]$ :

$$
\begin{aligned}
& \mathrm{Al}+\mathrm{OH}^{-} \rightarrow \mathrm{Al}(\mathrm{OH})_{a d s}+\mathrm{e}^{-} \\
& \mathrm{Al}(\mathrm{OH})_{a d s}+\mathrm{OH}^{-} \rightarrow \mathrm{Al}(\mathrm{OH})_{2 a d s}+\mathrm{e}^{-} \\
& \mathrm{Al}(\mathrm{OH})_{2 a d s}+\mathrm{OH}^{-} \rightarrow \mathrm{Al}(\mathrm{OH})_{3 a d s}+\mathrm{e}^{-}
\end{aligned}
$$

$\mathrm{An} \mathrm{Al}(\mathrm{OH})_{3}$ film is formed because $\mathrm{Al}^{3+}$ ions are thermodynamically unstable in the alkaline solution. The final step involves the dissolution of the hydroxide film forming soluble aluminate ions in the electrolyte and the regeneration of a bare aluminium surface site.

$\mathrm{Al}(\mathrm{OH})_{3}+\mathrm{OH}^{-} \rightarrow \mathrm{Al}(\mathrm{OH})_{4}^{-}$

At the same time, water is reduced on the aluminium surface according to a Volmer-Heyrovsky mechanism $[10,68]$.

$\mathrm{H}_{2} \mathrm{O}+\mathrm{e}^{-} \rightarrow \mathrm{H}_{a d s}+\mathrm{OH}^{-}$

$\mathrm{H}_{a d s}+\mathrm{H}_{2} \mathrm{O}+\mathrm{e}^{-} \rightarrow \mathrm{H}_{2}+\mathrm{OH}^{-}$

At longer times, the open-circuit potential shifts to more positive values and eventually stabilises at $-1.66 \mathrm{~V} v s$. $\mathrm{Hg} / \mathrm{HgO}$. This transient positive shift in open-circuit potential upon initial immersion is due to a lowering of solution $\mathrm{pH}$. As the aluminium 


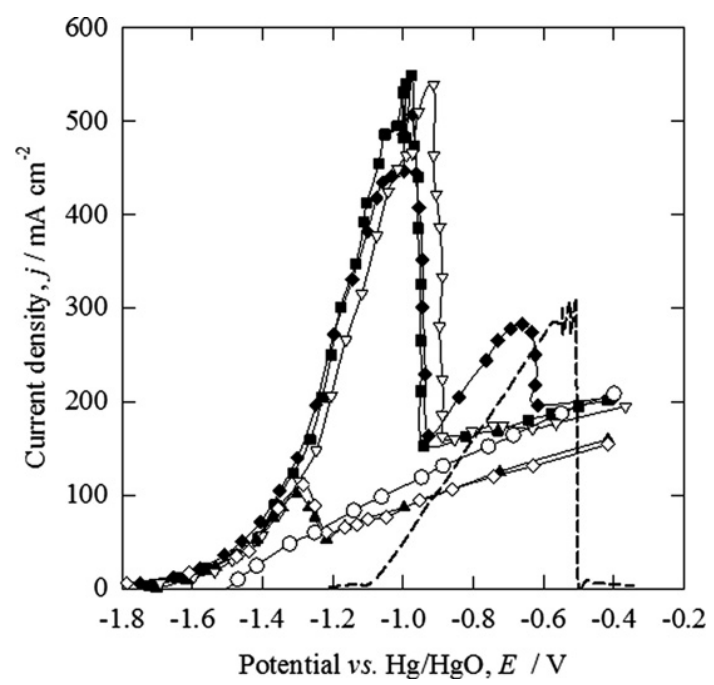

Fig. 3. Effect of tin concentration on the anodic polarisation of binary aluminium alloys in alkaline solutions at $25^{\circ} \mathrm{C}$. Data from rotating disc, potential sweep experiments performed on six Al/Sn alloys in $4 \mathrm{~mol} \mathrm{dm}^{-3} \mathrm{NaOH}$ [5,37]. Alloys were heat treated at $600{ }^{\circ} \mathrm{C}$ for $2 \mathrm{~h}$ followed by a water quench. Electrode area: $0.5 \mathrm{~cm}^{2}$. Potential sweep rate: $5 \mathrm{mV} \mathrm{s}^{-1}$. $20 \mathrm{~Hz}$ rotation speed. Counter-electrode, platinised titanium strip. $\bigcirc 99.995 \% \mathrm{Al}, \boldsymbol{\wedge} \mathrm{Al} / 0.044 \mathrm{wt} \% \mathrm{Sn}, \diamond \mathrm{Al} / 0.089 \mathrm{wt} \% \mathrm{Sn}, \boldsymbol{\mathrm { Al }} / 0.12 \mathrm{wt} \% \mathrm{Sn}, \nabla \mathrm{Al} /$ $0.23 \mathrm{wt} \% \mathrm{Sn}, \bullet \mathrm{Al} / 0.45 \mathrm{wt} \% \mathrm{Sn},----$ pure Sn.

oxidises, $\mathrm{OH}^{-}$ions are consumed at the interface and $\mathrm{Al}(\mathrm{OH})_{4}^{-}$ions are produced leading to passivation of the surface by a thicker $\mathrm{Al}(\mathrm{OH})_{3}$ film $[10,29]$ :

$2 \mathrm{Al}+2 \mathrm{OH}^{-}+6 \mathrm{H}_{2} \mathrm{O} \rightarrow 2 \mathrm{Al}(\mathrm{OH})_{4}^{-}+3 \mathrm{H}_{2}$

Anodic discharge of aluminium proceeds via the direct dissolution of the aluminium metal, whereby $\mathrm{OH}^{-}$ions migrate through the hydroxide layer, via Eq. (13) towards the interface between the aluminium and the hydroxide film, and indirect metal dissolution reaction by consecutive film formation and dissolution [29].

\section{Aluminium alloys}

Super-pure aluminium, in an uninhibited alkaline electrolyte, is unsuitable for use as the anode of an Al-air battery since (i) its surface is covered by a passive hydroxide layer creating high overpotentials during anodic dissolution and (ii) it suffers from high corrosion currents as water reduces on preferential surface sites evolving hydrogen. Alloying aluminium with particular elements improves its electrochemistry or activates it. The purpose of activation is to (a) reduce the overpotential for the oxidation by breaking down the passive hydroxide layer and (b) to increase the overpotential for the reduction of water on the surface.

Aluminium of purity greater than $99.99 \mathrm{wt} \%$, should be used as feedstock for the alloy because impurities such as copper, iron and silicon aggravate self-corrosion $[37,55,69]$. Such contaminants form cathodic sites of localised galvanic cells on the aluminium surface where hydrogen evolves because of their low overpotential for the hydrogen evolution reaction, see Table 1 $[70,71]$. In purity grades, such as $99.9 \mathrm{wt} \%$ aluminium, the levels of impurities such as iron exceed their solubility limit in aluminium and precipitate out as second phase particles; for example $\mathrm{Al}_{3} \mathrm{Fe}$ can act as cathodic centres for the generation of hydrogen, resulting in higher corrosion rates of the lower purity grades of aluminium [37,55].

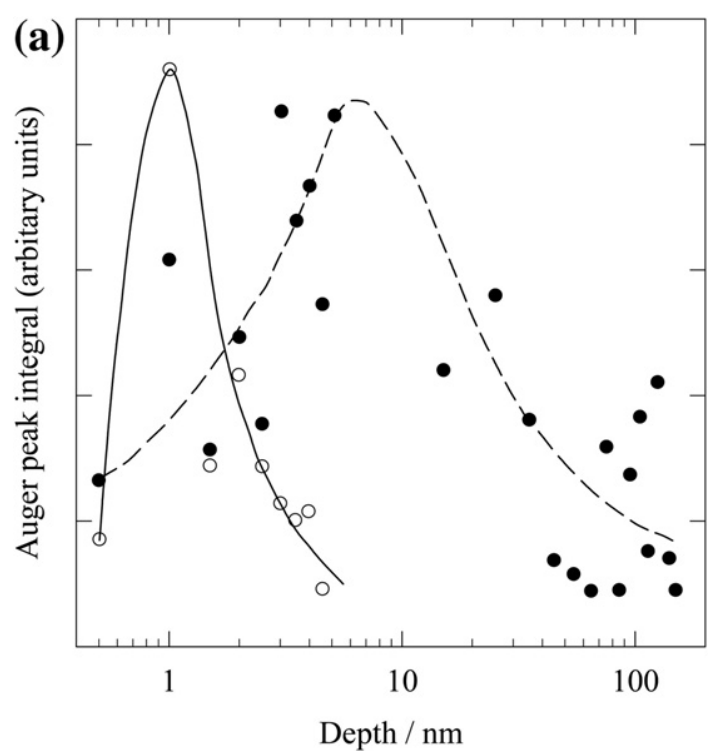

(b)

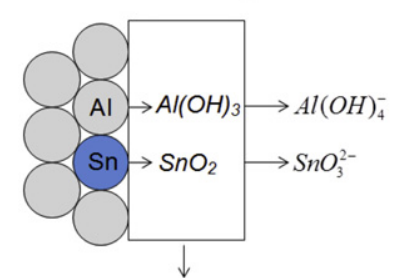

Metal

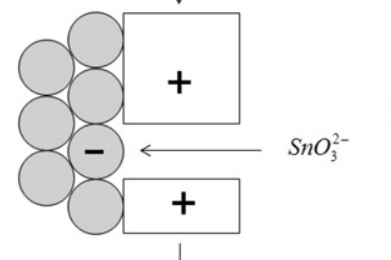

Electrolyte

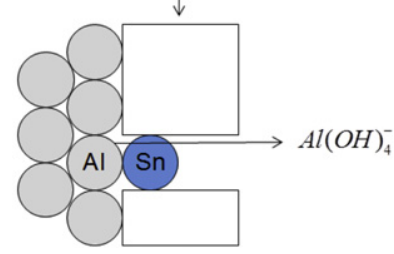

Fig. 4. (a) Auger depth profiles of oxidised and metallic tin on an $\mathrm{Al} / 0.1 \mathrm{Sn}$ exposed for $1 \mathrm{~h}$ in $1 \mathrm{~mol} \mathrm{dm}^{-3} \mathrm{NaOH}$ at an applied current density of $1 \mathrm{~mA} \mathrm{~cm}^{-2}$ [82]. Depth is measured from the top of the surface hydroxide layer. The alloy was heat treated at $620^{\circ} \mathrm{C}$ for $16 \mathrm{~h}$ and water quenched. Electrolyte temperature: $25^{\circ} \mathrm{C}$. $\bigcirc$ oxidised tin, $\bullet$ metallic tin. (b) Illustration of the activation mechanism.

\subsection{The influence of alloying elements and activation mechanisms}

An effective alloying element should possess the following properties: (i) a melting point below the melting temperature of aluminium $\left(657{ }^{\circ} \mathrm{C}\right.$ ), (ii) good solid solubility in the aluminium matrix, (iii) a higher nobility than aluminium in the electrochemical series as determined from the Pourbaix Diagram [19,72], (iv) good solubility in an alkaline electrolyte [37] and (v) a high hydrogen overpotential $[17,73]$. These properties are pivotal to the mechanisms by which the alloying elements activate the aluminium in alkaline solutions and are explained below.

The melting temperature of the alloying element should be lower than that of pure aluminium to facilitate its diffusion in the aluminium matrix via solution heat treatment to form a solid solution alloy. Alloying elements will only activate the aluminium when they are in solid solution with the aluminium matrix, yielding higher anodic currents compared to when they are present as 
Table 2

The open-circuit corrosion characteristics and discharge efficiencies of various binary aluminium alloys in half-cell tests. References ${ }^{\mathrm{a}}$ [5,37], ${ }^{\mathrm{b}}$ [75,189]. Electrolyte, 4 mol dm ${ }^{-3}$ $\mathrm{NaOH}$ at $60{ }^{\circ} \mathrm{C}$. Solution heat treatments: $600{ }^{\circ} \mathrm{C}$ for ${ }^{\mathrm{a}} 2 \mathrm{~h}$ and ${ }^{\mathrm{b}} 8 \mathrm{~h}$ followed by water quench. $\varphi_{\text {inh }}$ is the inhibition efficiency at open-circuit, defined as the percentage difference between the corrosion of the alloy and that of pure aluminium. $\varphi_{\text {dis }}$ is the discharge efficiency.

\begin{tabular}{|c|c|c|c|c|c|c|c|c|c|}
\hline \multirow[t]{3}{*}{ Alloy } & \multirow{3}{*}{$\begin{array}{l}\% \text { inhibition efficiency } \\
\text { at open-circuit } \\
\% \varphi_{\text {inh }}\end{array}$} & \multicolumn{4}{|c|}{ \% discharge efficiency under galvanostatic discharge } & \multicolumn{4}{|c|}{ Electrode potential during galvanostatic discharge } \\
\hline & & \multicolumn{4}{|c|}{$\% \varphi_{\text {dis }}$ at $j$ in $\mathrm{mA} \mathrm{cm}^{-2}$} & \multicolumn{4}{|c|}{ E vs. $\mathrm{Hg} / \mathrm{HgO} / \mathrm{V}$} \\
\hline & & 50 & 200 & 300 & 600 & $E_{o c}$ & $E_{50}$ & $E_{200}$ & $E_{600}$ \\
\hline \multicolumn{10}{|l|}{ Binary alloys } \\
\hline \multicolumn{10}{|l|}{ Tin } \\
\hline $\mathrm{Al} / 0.022 \mathrm{Sn}^{\mathrm{a}}$ & -597 & 9 & 12 & & & -1.78 & -1.79 & -1.70 & \\
\hline $\mathrm{Al} / 0.044 \mathrm{Sn}^{\mathrm{a}}$ & 26 & 15 & 45 & & & & -1.73 & -1.67 & \\
\hline $\mathrm{Al} / 0.089 \mathrm{Sn}^{\mathrm{a}}$ & 44 & 25 & 62 & & & -1.77 & -1.74 & -1.62 & \\
\hline $\mathrm{Al} / 0.12 \mathrm{Sn}^{\mathrm{a}}$ & 67 & 35 & 68 & & & -1.70 & -1.73 & -1.63 & \\
\hline \multicolumn{10}{|l|}{ Gallium } \\
\hline $\mathrm{Al} / 0.013 \mathrm{Ga}^{\mathrm{a}}$ & -370 & & & 58 & & -1.78 & & & \\
\hline $\mathrm{Al} / 0.026 \mathrm{Ga}^{\mathrm{a}}$ & -1370 & & & 61 & & -1.85 & & & \\
\hline $\mathrm{Al} / 0.055 \mathrm{Ga}^{\mathrm{a}}$ & -1627 & & & 50 & & -1.86 & & & \\
\hline $\mathrm{Al} / 0.10 \mathrm{Ga}^{\mathrm{a}}$ & -4324 & & & 7 & & -1.85 & & & \\
\hline $\mathrm{Al} / 0.24 \mathrm{Ga}^{\mathrm{a}}$ & -2839 & & & 7 & & -1.89 & & & \\
\hline $\mathrm{Al} / 2.3 \mathrm{Ga}^{\mathrm{a}}$ & -7036 & & & 3 & & -1.89 & & & \\
\hline \multicolumn{10}{|l|}{ Indium } \\
\hline $\mathrm{Al} / 0.02 \mathrm{In}^{\mathrm{a}}$ & 65 & 35 & 63 & & & -1.88 & -1.78 & -1.68 & \\
\hline $\mathrm{Al} / 0.037 \mathrm{In}^{\mathrm{a}}$ & 85 & 51 & 65 & & & -1.85 & -1.76 & -1.72 & \\
\hline $\mathrm{Al} / 0.074 \mathrm{In}^{\mathrm{a}}$ & 95 & 7 & 40 & & & -1.80 & -1.78 & -1.71 & \\
\hline $\mathrm{Al} / 0.16 \mathrm{In}^{\mathrm{a}}$ & 88 & 5 & 23 & & & -1.77 & -1.78 & -1.72 & \\
\hline $\mathrm{Al} / 0.21 \mathrm{In}^{\mathrm{a}}$ & 26 & 5 & 21 & & & -1.79 & -1.78 & -1.70 & \\
\hline $\mathrm{Al} / 0.42 \mathrm{In}^{\mathrm{a}}$ & 96 & 5 & 21 & & & -1.74 & -1.77 & -1.70 & \\
\hline $\mathrm{Al} / 0.15 \mathrm{Mn}^{\mathrm{b}}$ & 76 & & 55 & & Passive & -1.69 & & -1.52 & \\
\hline $\mathrm{Al} / 0.04 \mathrm{Fe}^{\mathrm{b}}$ & -89 & & 40 & & 74 & -1.45 & & -1.39 & -1.34 \\
\hline $\mathrm{Al} / 0.81 \mathrm{Mg}^{\mathrm{b}}$ & -1876 & & 4 & & 11 & & & & \\
\hline
\end{tabular}

precipitates $[23,63,74]$. As precipitates, the alloying elements aggravate the self-corrosion of the aluminium and decrease its efficiency $[50,73,75]$. Heating for $8 \mathrm{~h}$ at $600{ }^{\circ} \mathrm{C}$, followed by rapid cooling or quenching in water to suppress precipitation of alloying elements is a suitable heat treatment to achieve a solid solution alloy $[73,75,76]$. The heat treatment temperature can be determined from the phase diagram of the particular alloy [77,78].

The third desirable property of the alloying element is that it should be more noble than aluminium in the galvanic series [19,72]. This is key to the mechanism by which the alloying element activates aluminium in alkaline solutions, the metal dissolutiondeposition process $[19,23,79,80]$, which will be described in relation to a binary $\mathrm{Al} / 0.12 \mathrm{Sn}$ solid solution alloy. The anodic behaviour of $\mathrm{Al} / 0.12 \mathrm{Sn}$ is superior to that of pure aluminium, as shown in Fig. 3, over a potential range corresponding to the region of stability for tin in $\mathrm{pH} 14$ electrolyte i.e. between the $\mathrm{SnH}_{4} / \mathrm{Sn}$ reversible potential of $-1.86 \mathrm{~V} v s$. $\mathrm{Hg} / \mathrm{HgO}$ to the $\mathrm{Sn} / \mathrm{SnO}_{3}^{2-}$ reversible potential of $-1.06 \mathrm{~V} v s$. $\mathrm{Hg} / \mathrm{HgO}$, predicted by the Pourbaix Diagram [37,81]. As the $\mathrm{Al} / 0.12 \mathrm{Sn}$ undergoes anodic polarisation, tin atoms in solid solution become exposed and subsequently oxidise [72]. These oxidised species of tin are only present in the outermost few monolayers of the aluminium passive film, as indicated by Auger depth profiling in Fig. 4a [82]. The oxidised tin is soluble in alkaline solutions and dissolves into the electrolyte as stannate ions and if the potential of the aluminium is more negative than the $\mathrm{Sn}^{0} / \mathrm{SnO}_{3}^{2-}$ reversible potential, the $\mathrm{SnO}_{3}^{2-}$ ions reduce at cathodic sites on the aluminium surface to form metallic tin, as illustrated in Fig. 4b [72]. Auger depth profiling verified a high concentration of metallic tin on the outer surface of the alloy, which gradually decayed towards its bulk value in the metal (Fig. 4a) [82]. The forming of tin deposits serves three functions: (a) it promotes the further dissolution of aluminium, by destabilising the passive layer, (b) it prevents the electrolyte becoming saturated with stannate ions and (c) it reduces the self-corrosion of the aluminium, as tin's overpotential for hydrogen evolution is higher than it is for pure aluminium (Table 1)
[37]. Once the potential of aluminium becomes more positive than the $\mathrm{Sn}^{0} / \mathrm{SnO}_{3}^{2-}$ reversible potential the anodic behaviour of the alloy reverts back to the behaviour of pure aluminium, see Fig. 3. This is because $\mathrm{SnO}_{3}^{2-}$ ions in the electrolyte no longer redeposit onto the electrode surface and their concentration in the alkaline electrolyte increases. When the saturation level for $\mathrm{SnO}_{3}^{2-}$ ions in the electrolyte is reached, any further tin atoms in the solid solution alloy that become exposed and oxidised no longer dissolve into the electrolyte and remain on the aluminium surface, passivating it.

An alternative activation mechanism, the point defect effect one $[19,76,83]$, proposes that the metal ions of the alloying element present within the passive layer itself, reduces to form deposits at the interface between the alloy and the passive layer. Local swelling, during growth of these deposits, causes partial destruction and thinning of the passive film forming surface pits. This mechanism appears to fall down since it does not explain the activation of pure aluminium solely by metal ions introduced to the electrolyte as additives.

Regardless of the discrepancy between the dissolutiondeposition and point defect mechanisms, there is a general consensus that the reduced species of the alloying element is in intimate contact with the base alloy. The observation that the amount of gallium on the surface of an anodically discharged $\mathrm{Al} / \mathrm{Ga}$ alloy had diminished following several days storage is evidence of back diffusion into the alloy bulk, facilitated by the intimate contact with the gallium and the aluminium alloy. A driving force for back diffusion exists because of the lower concentration of the gallium in the bulk. Back diffusion could play a determining role as to whether a certain concentration of an alloying element enhances the anodic behaviour of the aluminium since a particular minimum surface concentration of the reduced metal species must be present to achieve activation [76].

These reduced deposits on the aluminium surface are free of a passive hydroxide layer and the aluminium diffuses through them to be oxidised $[37,76,82]$. These deposits are likely in a liquid state 

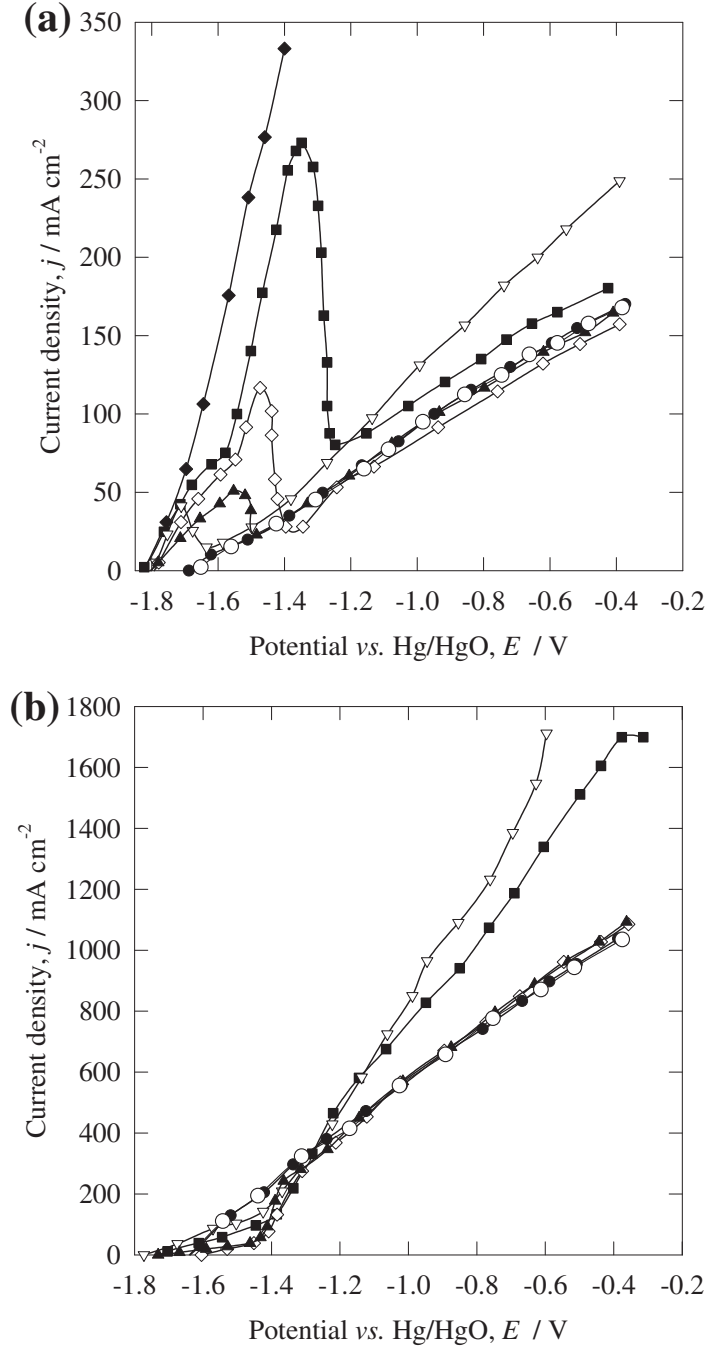

Fig. 5. Effect of gallium content on the polarisation behaviour of $\mathrm{Al} / \mathrm{Ga}$ alloys in a $4 \mathrm{~mol} \mathrm{dm}{ }^{-3} \mathrm{NaOH}$ solution at (a) $25{ }^{\circ} \mathrm{C}$ and (b) $60{ }^{\circ} \mathrm{C}$. Results from rotating disc electrode tests. Electrode area, $0.5 \mathrm{~cm}^{2}$. Potential sweep rate $5 \mathrm{mV} \mathrm{s}^{-1}$. Rotation speed: $20 \mathrm{~Hz}$. Counter-electrode: platinised titanium strip. Alloys were heat treated at $600{ }^{\circ} \mathrm{C}$ for $2 \mathrm{~h}$ followed by a water quench. $\bigcirc 99.995 \% \mathrm{Al}, \bullet \mathrm{Al} / 0.013 \% \mathrm{Ga}, \boldsymbol{\Delta} \mathrm{Al} / 0.026 \% \mathrm{Ga}$, $\diamond$ $\mathrm{Al} / 0.055 \% \mathrm{Ga}, \mathrm{Al} / 0.10 \% \mathrm{Ga}, \nabla \mathrm{Al} / 0.24 \% \mathrm{Ga}, \mathrm{Al} / 2.3 \% \mathrm{Ga}$.

owing to the low melting temperature of some of the alloying elements, in particular gallium, and also due to the anodic current concentrating at these surface deposits creating extremely large current densities [18]. Differential scanning calorimetry supports the likelihood of liquid surface deposits through which the aluminium can diffuse [84,85].

Research on alloys for aluminium-air batteries has focused on $\mathrm{Mg}, \mathrm{Zn}, \mathrm{Pb}, \mathrm{Sn}, \mathrm{Ga}, \mathrm{In}, \mathrm{Mn}, \mathrm{Hg}$ and $\mathrm{Tl}$ alloying elements, because these elements have lower melting temperatures than aluminium (with the exception of $\mathrm{Mn}$ ), have a degree of solubility in aluminium, are more noble than aluminium (with the exception of $\mathrm{Mg}$ ), are soluble in alkaline electrolytes and have a high hydrogen overpotential, as shown in Table 1 . Today, mercury and thallium cannot be considered due to their toxicity. In the next section, the effect of different alloying elements on the anodic behaviour and corrosion of super-pure aluminium (minimum $99.99 \mathrm{wt} \%$ ) in sodium and potassium hydroxide solutions is discussed. Several studies have looked at the effect of alloying elements on more commercially pure aluminium [70,86-90]. The data from these have not been included in this review in order to elucidate the effect of different alloying elements, without any
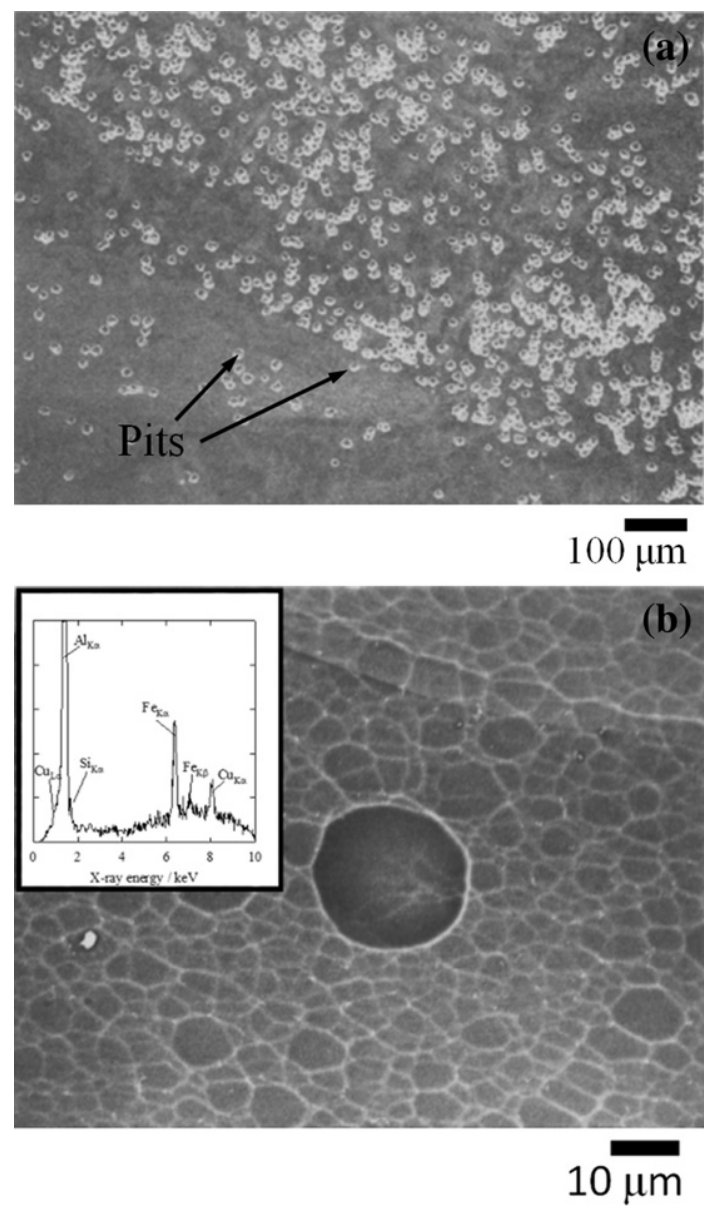

Fig. 6. Comparison of the surface morphology of $99.999 \% \mathrm{Al}$ and $\mathrm{Al} / 0.05 \% \mathrm{Ga}$ alloy under galvanostatic discharge. (a) SEM image of Al/0.05Ga alloy under a $100 \Omega$ discharge $4 \mathrm{~s}$ after activation [76]. Discharge in a micro Al-air cell with a $4 \mathrm{~mol} \mathrm{dm}^{-3}$ $\mathrm{NaOH}$ solution at $60{ }^{\circ} \mathrm{C}$. Anode area, $1 \mathrm{~cm}^{2}$. Co-catalysed air cathode supplied by Electromedia Corp. Alloy heat treated at $600{ }^{\circ} \mathrm{C}$ for at least $2 \mathrm{~h}$ followed by a water quench. (b) Back scatter electron image of $99.999 \% \mathrm{Al}$ discharged at $300 \mathrm{~mA} \mathrm{~cm}{ }^{-2}$ for $5 \mathrm{~min}$ in an $\mathrm{Al}$-air cell [37]. Inset: EDX of the boundary of the large shallow pits.

misreading results from impurities such as iron and copper. Studies where the alloys were not solution heat treated or homogenised prior to testing were also not included in this review [61,79,91-94], since as discussed above, the alloying elements must be in solid solution to be effective at activating the aluminium alloy surface.

\subsection{Alloying elements}

\subsubsection{Tin}

The dissolution behaviour of $\mathrm{Al} / \mathrm{Sn}$ binary alloys is influenced by the structure, concentration and electrochemistry of tin along with the electrolyte temperature. The upper limit for the tin concentration in a binary aluminium alloy for use in aluminium-air batteries is $0.12 \mathrm{wt} \%$, as this is the maximum that can be accommodated in solid solution in the aluminium matrix. A suitable solution heat treatment involves heating at $600{ }^{\circ} \mathrm{C}$ for several hours, then water quenching $[5,50,78,95]$. An $\mathrm{Al} / 0.12 \mathrm{Sn}$ alloy showed the most anodic behaviour among a range of $\mathrm{Al} / \mathrm{Sn}$ binary alloys in a $4 \mathrm{~mol} \mathrm{dm}^{-3} \mathrm{NaOH}$ solution at $25{ }^{\circ} \mathrm{C}$, see Fig. 3. This alloy showed enhanced anodic currents compared to pure aluminium over a potential range corresponding to the region of stability for tin, as discussed earlier [37,81]. Concentrations of tin lower than $0.12 \%$ in a $25{ }^{\circ} \mathrm{C}$ electrolyte, most likely had 

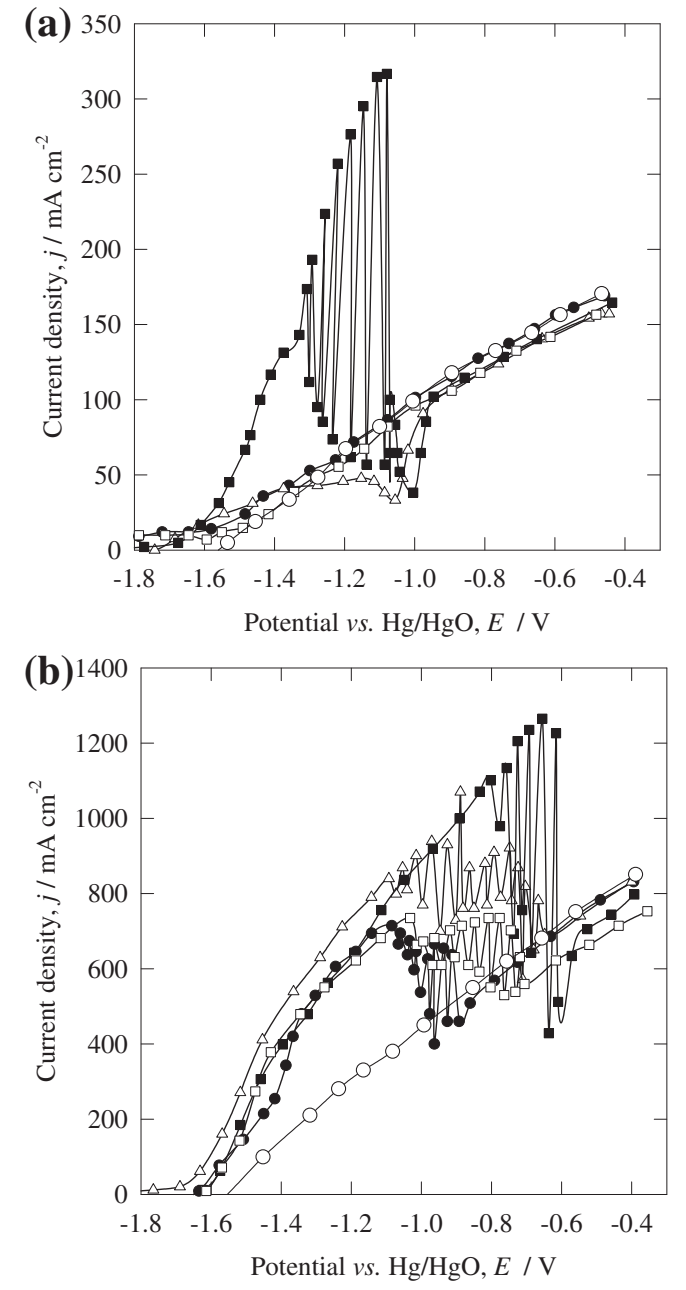

Fig. 7. Effect of indium concentration on the polarisation behaviour of $\mathrm{Al} / \mathrm{In}$ electrodes in $4 \mathrm{~mol} \mathrm{dm}-3 \mathrm{NaOH}$ at (a) $25^{\circ} \mathrm{C}$ and (b) $60^{\circ} \mathrm{C}$ [37]. Results from rotating disc electrode tests. Electrode area, $0.5 \mathrm{~cm}^{2}$. Potential sweep rate: $5 \mathrm{mV} \mathrm{s}$. Rotation speed: $20 \mathrm{~Hz}$. Counter-electrode: platinised titanium strip. Alloys were heat treated at $600{ }^{\circ} \mathrm{C}$ for $2 \mathrm{~h}$ followed by a water quench. $\bigcirc 99.995 \% \mathrm{Al}, \bullet \mathrm{Al} / 0.02 \mathrm{In}, \square \mathrm{Al} / 0.037 \mathrm{In}, \triangle \mathrm{Al} / 0.074 \mathrm{In}$, - Al/0.16 In. The anodic linear sweep curves for $\mathrm{Al} / 0.21 \mathrm{In}$ and $\mathrm{Al} / 0.42 \mathrm{In}$ were identical to that of $\mathrm{Al} / 0.16 \mathrm{In}$ and are excluded to simplify the graphs.

fewer tin deposits formed during the dissolution-deposition process to accommodate film-free dissolution of aluminium. The alloys with tin levels greater than $0.12 \%$ did not improve the anodic current peak at $-1.0 \mathrm{~V} v \mathrm{~s}$. $\mathrm{Hg} / \mathrm{HgO}$, see Fig. 3, because the excess tin was present as second phase particles on their grain boundaries which are ineffective at activating aluminium, as discussed earlier [37]. The anodic peak at $-0.66 \mathrm{~V}$ vs. $\mathrm{Hg} / \mathrm{HgO}$ in Fig. 3 for $\mathrm{Al} / 0.45 \mathrm{Sn}$ alloy was due to the oxidation of these second phase particles, which resulted in pronounced grain boundary attack and potential disintegration of surface grains upon anodic discharge, as verified under the SEM [37].

Since the maximum solubility limit of $0.12 \%$ Sn changes when alloying with a ternary element, lower concentrations of tin would be required when forming a ternary or quaternary alloy to ensure a solid solution can be achieved. The effect of lower tin concentrations is strongly influenced by the electrolyte temperature. At $25^{\circ} \mathrm{C}$ they did little to improve upon the anodic currents observed for pure aluminium (Fig. 3), whereas at $60{ }^{\circ} \mathrm{C}$ binary alloys with concentrations ranging from 0.022 up to $0.12 \%$ Sn showed identical anodic behaviour. This is indicated by the marginal differences among the galvanostatic discharge potentials shown in Table 2. It was the corrosion behaviour that separated the tin concentrations
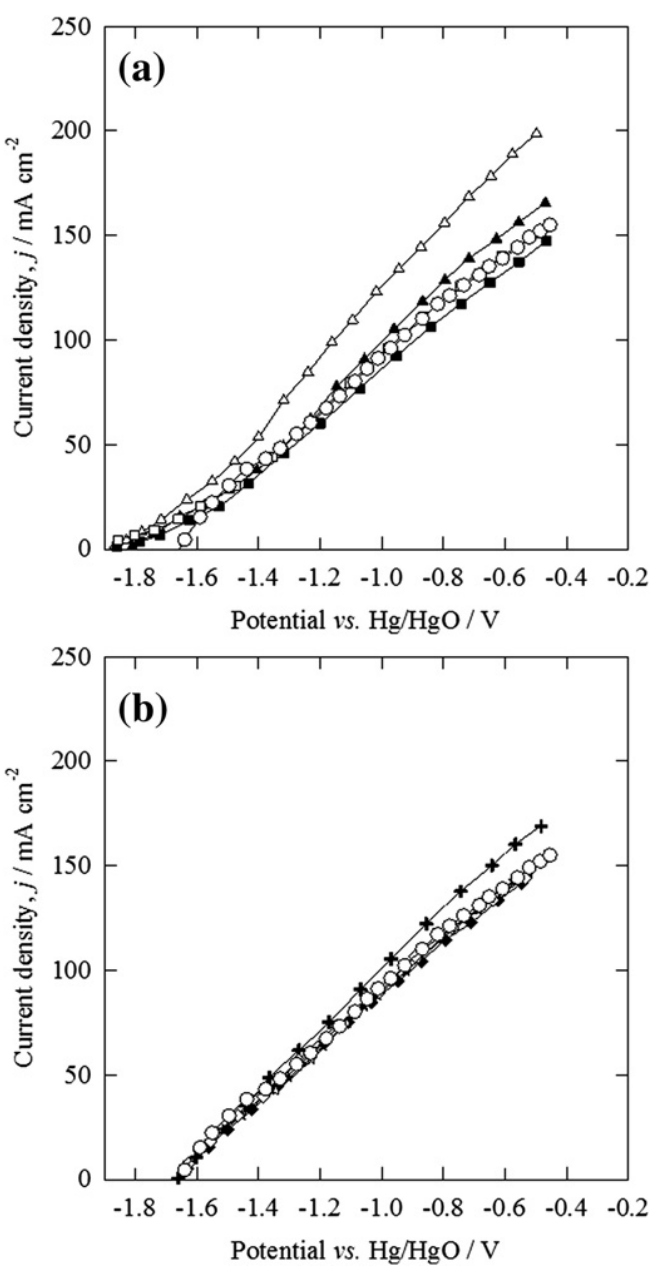

Fig. 8. Anodic linear sweep voltammograms of other binary aluminium alloys in $4 \mathrm{~mol} \mathrm{dm}{ }^{-3} \mathrm{NaOH}$ solution at $25^{\circ} \mathrm{C}[37,211]$. Results from rotating disc electrode tests. Electrode area, $0.5 \mathrm{~cm}^{2}$. Potential sweep rate $5 \mathrm{mV} \mathrm{s}^{-1}$. Rotation speed: $20 \mathrm{~Hz}$. Counterelectrode: platinised titanium strip. Alloys were heat treated at $600{ }^{\circ} \mathrm{C}$ for $2 \mathrm{~h}$ followed by a water quench. (a) $\bigcirc 99.995 \% \mathrm{Al}, \Delta \mathrm{Al} / 0.004 \mathrm{P}, \Delta \mathrm{Al} / 0.02 \mathrm{Sb}, \square \mathrm{Al} / 0.02 \mathrm{Cd}, \square \mathrm{Al} /$ $0.004 \mathrm{C}$. (b) $\bigcirc 99.995 \% \mathrm{Al}, \diamond \mathrm{Al} / 0.01 \mathrm{Bi},+\mathrm{Al} / 0.01 \mathrm{Zn}, \star \mathrm{Al} / 0.005 \mathrm{Si}, \star \mathrm{Al} / 0.02 \mathrm{~B}, \diamond \mathrm{Al} /$ $0.04 \mathrm{Ge}$.

at $60{ }^{\circ} \mathrm{C}$, with $\mathrm{Al} / 0.12 \mathrm{Sn}$ exhibiting the highest inhibition and discharge efficiencies, as shown in Table 2.

Some $\mathrm{Al} / \mathrm{Sn}$ alloys were active at $60^{\circ} \mathrm{C}$ and not at $25^{\circ} \mathrm{C}$; this can be explained by the increasing solubility of aluminate with increasing temperature allowing more of the $\mathrm{Al}(\mathrm{OH})_{3}$ passive film to dissolve into the electrolyte [10,79]. The subsequent thinner passive film allowed easier transfer of $\mathrm{OH}^{-}$ions to pass through it, leading to a faster rate of aluminium dissolution [33]. However a thinner passive film also provides lower resistance to the conduction of electrons to the cathodic sites on the aluminium surface, where they are consumed by the reduction of water evolving hydrogen [68]. Consequently, the corrosion current also increases. The improved behaviour at the higher elevated temperature may also be due to a faster rate of diffusion of aluminium through the surface tin at the higher temperature, higher solubility for the $\mathrm{SnO}_{3}^{2-}$ ion and the reversible potential for $\mathrm{Sn} / \mathrm{SnO}_{3}^{2-}$ may be shifted more positive. This would also explain why the potential range of enhanced anodic behaviour observed in the anodic polarisation curves at $25^{\circ} \mathrm{C}$ was not evident at $60^{\circ} \mathrm{C}$, under the experimental conditions.

\subsubsection{Gallium}

The electrochemistry of $\mathrm{Al} / \mathrm{Ga}$ alloys in alkaline electrolytes is dependent on the gallium content in the alloy, the electrolyte 
temperature and the electrochemistry of gallium. At an electrolyte temperature of $25^{\circ} \mathrm{C}$, gallium contents of $0.055 \mathrm{wt} \%$ or higher were required to enhance the anodic currents of pure aluminium, see Fig. 5a [37]. At $60{ }^{\circ} \mathrm{C}$, at least $0.1 \%$ Ga was required, see Fig. 5b. A certain level of surface gallium is required to activate the aluminium [76]. Whether an alloy achieves this critical level is dependent on the rate of dissolution of the aluminium, the formation of gallium deposits via the dissolution-deposition process and the rate of back diffusion of gallium from the surface into the alloy bulk.

The corrosion behaviour of $\mathrm{Al} / \mathrm{Ga}$ alloys in an alkaline electrolyte at $60{ }^{\circ} \mathrm{C}$ is shown in Table $2[37,74]$. At open-circuit, the corrosion rate of all the binary $\mathrm{Al} / \mathrm{Ga}$ alloys was extremely high with very negative inhibition efficiencies. The effect of gallium content on discharge efficiency was dependent on whether the alloy was activated or not, with the activated alloys showing very poor discharge efficiencies i.e. those with gallium levels above $0.1 \%$. In the case of $\mathrm{Al} / 2.3 \% \mathrm{Ga}$, scanning electron microscopy examination showed that it suffered severe grain boundary attack leading to disintegration. Corrosion data for $\mathrm{Al} / \mathrm{Ga}$ alloys at $25{ }^{\circ} \mathrm{C}$ or other intermediate temperatures was not evident in the literature. It is likely that at temperatures below the low melting temperature of gallium, $29^{\circ} \mathrm{C}$, the diffusion of aluminium through solid gallium deposits would be slower and hence the rate of water reduction and corrosion would be less [76]. These gallium deposits are found at the base of pits on the alloy surface and on top of the surface hydroxide layer, as indicated in Fig. 6a [76]. The evidence of pits indicates that the anodic current is concentrated at very small sites on the surface $[96,97]$.

This contrasts with the surface of $99.999 \%$ aluminium which was characterised by a network of broad shallow pits of between 3 and $10 \mu \mathrm{m}$ diameter (Fig. 6b) [37]. These pits were formed via galvanic corrosion initiated by the potential difference between aluminium and its more positive or anodic hydroxide layer [96,97]. The inset EDX profile in Fig. $6 \mathrm{~b}$ shows that the boundaries of the pits were brighter due to heavier impurity elements, Si, Fe and $\mathrm{Cu}$ left from the manufacturing process, concentrating in these regions. The pit centres on the pure $\mathrm{Al}$ were covered by a passive hydroxide layer and were more anodic or positive to their boundaries. At the pit centres, $\mathrm{OH}^{-}$ions migrated through the hydroxide layer to oxidise the underlying aluminium. The released electrons were conducted through the external circuit but also towards the pit boundaries, which were more negative or cathodic to the pit centres. Here the electrons were consumed by the reduction of water to evolve hydrogen and also for the reduction of the iron and copper ions. The hydrogen evolution reaction generated $\mathrm{OH}^{-}$ions maintaining a high $\mathrm{pH}$ at the boundaries, preventing their passivation. The pits on the pure Al surface were broad, shallow and interconnected indicating the anodic current density was reasonably distributed across the whole aluminium surface.

\subsubsection{Indium}

The electrochemistry of $\mathrm{Al} / \mathrm{In}$ alloys is dependent on the amount of In in the alloy, the electrolyte temperature and the electrochemistry of indium [37,74]. The upper limit for the indium concentration in a binary aluminium alloy for use in aluminiumair batteries is $0.16 \%$, which is close to the solid solubility limit for indium in aluminium at a heat treatment temperature of $640{ }^{\circ} \mathrm{C}$. $\mathrm{Al} / 0.16 \mathrm{In}$ showed the highest anodic currents in a solution of $4 \mathrm{~mol} \mathrm{dm}^{-3} \mathrm{NaOH}$ at $25{ }^{\circ} \mathrm{C}$ compared to other indium compositions examined, see Fig. 7a [37]. Higher indium concentrations showed no further improvement in the anodic behaviour, indicating that the polarisation behaviour was entirely controlled by the indium present in solid solution rather than by second phase particles.
Indium concentrations lower than the maximum solubility level only showed more active behaviour at an elevated temperature of $60{ }^{\circ} \mathrm{C}$, as indicated in Fig. 7b, or by increasing the electrolyte flow rate [37]. The enhancement in anodic behaviour with increase in electrolyte flow indicates that the alloys behaviour is not limited by the surface charge transfer, as is the case for pure aluminium in $4 \mathrm{~mol} \mathrm{dm}^{-3} \mathrm{NaOH}[10,33,55]$. Increasing electrolyte flow rate results in fast supply of $\mathrm{OH}^{-}$ions to the metal/solution interface and rapid removal of $\mathrm{Al}(\mathrm{OH})_{4}^{-}$ions away from the aluminium surface, allowing more of the $\mathrm{Al}(\mathrm{OH})_{3}$ layer to dissolve into the electrolyte, see Eq. (13) [29]. Among the literature, there has been no rotating disc electrode study evaluating the effect of rotation rate on the anodic and cathodic behaviour of aluminium alloys in alkaline solutions.

In terms of corrosion behaviour of $\mathrm{Al} / \mathrm{In}$ alloys at $60^{\circ} \mathrm{C}$, the data in Table 2 shows that inhibition and discharge efficiencies for $\mathrm{Al} / \mathrm{In}$ alloys are dependent on the percentage of indium in solid solution. $\mathrm{The} \mathrm{Al} / \mathrm{In}$ alloys with the lowest indium concentrations showed the higher discharge efficiencies. In general the corrosion/hydrogen evolution behaviour of $\mathrm{Al} / \mathrm{In}$ alloys is very complex depending on the discharge time, current density, indium level and the degree of surface roughening [37].

Fig. 7 shows that there is a potential range over which the $\mathrm{Al} / \mathrm{In}$ alloys exhibit enhanced anodic currents compared to pure aluminium. This potential range corresponds with the region of stability of indium metal in $\mathrm{pH} 14$ electrolyte predicted by the Pourbaix Diagram, as discussed earlier. The Al/In alloys with enhanced anodic behaviour were characterised by lightly scalloped surfaces covered in indium agglomerates of $0.2-1 \mu \mathrm{m}$ diameter. These indium deposits on the surface of the passive layer were the active sites causing local destruction of this layer [36,98].

The anodic polarisation curve for $\mathrm{Al} / 0.16 \%$ In alloy at $25{ }^{\circ} \mathrm{C}$ exhibited current fluctuations between -1.3 and $-1.05 \mathrm{~V} v \mathrm{vs} . \mathrm{Hg} /$ $\mathrm{HgO}$, indicating that the alloy was alternating between a more active state and the state exhibited by pure aluminium. These fluctuations could have been caused by successive destruction and build-up of a passive hydroxide layer due to local variations in $\mathrm{pH}$ at the active sites [36]. A more likely reason to account for these fluctuations is the low solubility of indium in the alkaline electrolyte [37]. As the aluminium and indium dissolved from the alloy into the electrolyte, the local indate, $\mathrm{InO}_{2}^{-}$, concentration increased and eventually reached saturation in the electrolyte. At this point any further oxidised indium remained on the aluminium surface as $\mathrm{In}_{2} \mathrm{O}_{3}$, passivating the active sites. After a brief period of time, when the local indate concentration fell below the solubility limit (by diffusion or convection), the surface $\mathrm{In}_{2} \mathrm{O}_{3}$ could then dissolve into the electrolyte, and the rate of oxidation of the alloy increased again. This theory explains why the current fluctuations for an $\mathrm{Al} /$ $\mathrm{Sn}$ alloy (Fig. 3) were lower than that observed for the $\mathrm{Al} / \mathrm{In}$ alloys, as $\mathrm{SnO}_{3}^{2-}$ is more soluble in $\mathrm{pH} 14$ media than $\mathrm{InO}_{2}^{-}$. Similarly $\mathrm{GaO}_{3}^{2-}$ is more soluble in alkaline electrolyte than either $\mathrm{SnO}_{3}^{2-}$ or $\mathrm{InO}_{2}^{-}$, explaining why the $\mathrm{Al} / \mathrm{Ga}$ alloys showed no current fluctuations, see Fig. 5a. This hypothesis for the observed current fluctuations gives strength to the dissolution-deposition process as the mechanism of activation of aluminium alloys in alkaline electrolyte.

\subsubsection{Other binary aluminium alloys}

Examining other binary alloying elements, 0.15\% Mn reduced the self-corrosion of $99.99 \% \mathrm{Al}$ at open-circuit, see Table 2, and enhanced the anodic behaviour with a very negative potential of $-1.52 \mathrm{~V} v$ s. $\mathrm{Hg} / \mathrm{HgO}$ at $200 \mathrm{~mA} \mathrm{~cm}^{-2}$. The drawback is that $\mathrm{Mn}$ aggravated the parasitic corrosion during discharge, with a discharge efficiency of 55\% [75]. Using manganese as an alloying 
Table 3

The open-circuit corrosion characteristics and discharge efficiencies of various ternary and quaternary aluminium alloys in half-cell tests. References ${ }^{\mathrm{i}}[50],{ }^{\text {ii }}[75,189],{ }^{i i i}[190]$. The electrolyte temperature for each of these experiments was $60{ }^{\circ} \mathrm{C}$. Solution heat treatments: $600{ }^{\circ} \mathrm{C}$ for ${ }^{\text {ii }} 8 \mathrm{~h}$ and ${ }^{\text {iii }} 4 \mathrm{~h}$ followed by water quench. $\varphi$ inh is the inhibition efficiency at open-circuit. $\varphi_{\text {dis }}$ is the discharge efficiency.

\begin{tabular}{|c|c|c|c|c|c|c|c|c|c|}
\hline \multirow[t]{3}{*}{ Alloy } & \multirow{3}{*}{$\begin{array}{l}\% \text { inhibition eff. } \\
\text { at open- circuit } \\
\% \varphi_{\text {inh }}\end{array}$} & \multirow{2}{*}{\multicolumn{4}{|c|}{$\begin{array}{l}\% \text { discharge efficiency under } \\
\text { galvanostatic discharge } \\
\% \varphi_{\text {dis }} \text { at } j \text { in } \mathrm{mA} \mathrm{cm}^{-2}\end{array}$}} & \multicolumn{4}{|c|}{ Electrode potential during galvanostatic discharge } \\
\hline & & & & & & \multicolumn{4}{|c|}{ E vs. $\mathrm{Hg} / \mathrm{HgO} / \mathrm{V}$} \\
\hline & & 50 & 200 & 300 & 600 & $E_{o c}$ & $E_{50}$ & $E_{200}$ & $E_{600}$ \\
\hline \multicolumn{10}{|l|}{ Ternary E Quaternary alloys } \\
\hline $\mathrm{Al} / 0.5 \mathrm{Mg} / 0.07 \mathrm{Sn}^{\mathrm{i}}(\mathrm{EB} 50 \mathrm{~V})$ & & & 99 & & 99 & & & & \\
\hline $\mathrm{Al} / 0.84 \mathrm{Mg} / 0.13 \mathrm{Mn} / 0.11 \mathrm{In}^{\mathrm{ii}}$ (Alloy BDW) & 94 & & 91 & & 90 & -1.70 & & -1.69 & -1.64 \\
\hline $\mathrm{Al} / 0.12 \mathrm{Mn} / 0.11 \mathrm{In}^{\mathrm{ii}}$ & 79 & & 86 & & 88 & -1.76 & & -1.79 & -1.58 \\
\hline $\mathrm{Al} / 0.8 \mathrm{Mg} / 0.097 \mathrm{In}^{\mathrm{ii}}$ & 96 & & 87 & & 87 & -1.70 & & -1.70 & -1.59 \\
\hline $\mathrm{Al} / 0.40 \mathrm{Mg} / 0.04 \mathrm{Ga} / 0.10 \mathrm{Sn}^{\mathrm{ii}}(\mathrm{AB} 50 \mathrm{~V})$ & 60 & & 86 & & 100 & -1.73 & & -1.63 & -1.63 \\
\hline $\mathrm{Al} / 0.1 \mathrm{Ga} / 0.1 \mathrm{In} / 0.1 \mathrm{~Pb}^{\mathrm{iii}}$ & 90 & & & & & & & & \\
\hline $\mathrm{Al} / 0.14 \mathrm{Mn} / 0.84 \mathrm{Mg}^{\mathrm{ii}}$ & -1876 & & 4 & & 11 & & & & \\
\hline $\mathrm{Al} / 0.80 \mathrm{Mg} / 0.04 \mathrm{Ga}^{\mathrm{ii}}$ & -1876 & & 4 & & 11 & -1.87 & & -1.73 & -1.65 \\
\hline
\end{tabular}

element has been shown to reduce the rate of corrosion of $99.9 \%$ aluminium which contains high levels of iron [63].

The linear sweep voltammograms for a range of other binary aluminium alloys are shown in Fig. 8. These binary alloys seem to have no improvement on the anodic behaviour of pure aluminium because their alloying levels are well below their solid solubility limit, listed in Table 1. An improvement in anodic behaviour may be seen if the alloying levels were increased to the limit of their solid solubility in aluminium.

Some binary aluminium alloys such as $\mathrm{Al} / \mathrm{Zn}$ exhibit opencircuit potentials close to the potential at which the alloying element is oxidised in alkaline solutions. In comparison, other alloying elements like indium and tin shift the open-circuit potential of aluminium towards the potential at which they are reduced in alkaline solutions. This may be due to indium and tin having a wider stability window than zinc in alkaline solutions and the more negative potential of the base aluminium can shift the potential of the tin and indium towards their reversible reduction potentials. In the case of lead, heat treatment of an $\mathrm{Al} / 0.006 \mathrm{~Pb}$ alloy at $630{ }^{\circ} \mathrm{C}$ followed by water quenching showed that lead has a tendency to become enriched at the aluminium oxide interface, as indicated by depth profiling [99]. The segregations formed because of the extremely small solid solubility of lead in aluminium [99].

The addition of magnesium to aluminium improves its impurity intolerance most probably because the magnesium forms compounds with elements like silicon, preventing them from reducing on cathodic sites to act as centres for hydrogen evolution [64,68]. It also improves the mechanical properties of aluminium such as its hardness and strength $[68,100]$. A magnesium concentration of $0.81 \%$ significantly aggravated the self-corrosion of $99.99 \% \mathrm{Al}$ at open-circuit and during discharge, as indicated in Table 2 [75]. As $\mathrm{Mg}$ is more noble metal than aluminium, it will not redeposit at the cathodic sites on the aluminium surface. These sites are left exposed to the solution upon which water reduces, evolving hydrogen gas. The characteristics of the passive films formed on $\mathrm{Al} /$ Mg alloys were investigated using in-situ ellipsometry [101]. Those results are not detailed here because limitations of the technique meant the use of potentials more positive than those experienced by the aluminium anode in the battery $[101,102]$.

\subsubsection{Ternary and quaternary aluminium alloys and polarisation dominance}

Several studies have shown that the discharge and polarisation characteristics of alloys containing two or more alloying elements are controlled by one dominant species [37,98]. There exists a dominance sequence among tin, indium and gallium, with tin being dominant in an $\mathrm{Al} / \mathrm{Sn} / \mathrm{In} / \mathrm{Ga}$ alloy and indium being dominant in an
$\mathrm{Al} / \mathrm{In} / \mathrm{Ga}$ alloy. This dominance was verified by overlapping anodic polarisation curves between ternary or quaternary alloys and the binary alloy of the dominant species. The dominance sequence corresponds with the order of the melting points of the alloying elements and their rate of diffusion. As the alloying elements plate out from the electrolyte onto the surface of the aluminium, a concentration gradient of the alloying element is set up, with a high concentration on the surface, decreasing towards the bulk of the alloy. This concentration gradient provides a driving force for the diffusion of the alloying element from the surface towards the bulk. The higher the melting point of an element in a solid solution alloy with aluminium, the slower its back diffusion from the surface of the alloy [37]. This extends its retention on the surface allowing it to control the thinning of the passive film and diffusion of aluminium towards a film-free surface to be oxidised. The dominance of one element upon the discharge characteristics does not mean that it is the only one retained as an agglomerate on the aluminium surface. In the case of $\mathrm{Al} / \mathrm{Sn} / \mathrm{In} / \mathrm{Ga}$ alloy, all three alloying elements were retained upon the surface after discharge.

Researchers have tested a variety of ternary and quaternary aluminium alloys, of which the corrosion and anodic discharge characteristics are compared in Table 3. The general aim, when alloying different elements together with aluminium, was to improve upon the behaviour of the binary alloys discussed above, such as to enhance the anodic currents delivered by $\mathrm{Al} / \mathrm{Sn}$ alloys or to reduce the self-corrosion of $\mathrm{Al} / \mathrm{In}$ alloys. An alloy that received much attention was named Alloy BDW, Al/0.84Mg/0.13Mn/0.11In [75]. It attained discharge efficiencies over $90 \%$ at $600 \mathrm{~mA} \mathrm{~cm}^{-2}$ at a potential of $-1.64 \mathrm{~V} v s . \mathrm{Hg} / \mathrm{HgO}$ in a solution at $60^{\circ} \mathrm{C}$, (Table 3).

The aluminium alloy optimised for an Alupower ${ }^{\mathrm{TM}}$ battery was 99.999\% aluminium alloyed with $0.07 \mathrm{wt} \%$ tin and $0.5 \mathrm{wt} \% \mathrm{mag}-$ nesium, known as EB50V [50,61]. Its discharge efficiencies exceeded $90 \%$ at current densities above $50 \mathrm{~mA} \mathrm{~cm}^{-2}$, see Table 3. These efficiencies were higher than those of a binary alloy with a similar composition of tin. Perhaps the magnesium is contributing to reducing the parasitic corrosion when added to an $\mathrm{Al} / \mathrm{Sn}$ alloy [101]. The composition of this alloy was optimised for use under these nominal conditions: $8 \mathrm{~mol} \mathrm{dm}^{-3} \mathrm{KOH}, 60{ }^{\circ} \mathrm{C}$ with addition of $0.01 \mathrm{~mol} \mathrm{dm}^{-3}$ sodium stannate as a corrosion inhibitor [61].

All the aluminium alloys in Table 3 were evaluated at an elevated temperature of $60^{\circ} \mathrm{C}$ which is the optimum temperature for an aluminium-air system [103]. Among the research that adhered to the sample preparation requirements regarding solution heat treatment, none of them carried out tests at intermediate temperatures between 20 and $60{ }^{\circ} \mathrm{C}$. An alloy attaining high discharge rates at $60^{\circ} \mathrm{C}$, may not attain the same anodic currents at room temperature, as shown for $\mathrm{Al} / \mathrm{Ga}$ alloys in Fig. 5. This is 
Table 4

Effect of solution phase inhibitors on inhibiting the corrosion rate of $\mathrm{Al}$ in alkaline solutions at open-circuit and under discharge in half-cell tests. ${ }^{\mathrm{a}}$ [32], ${ }^{\mathrm{b}}$ [109], ${ }^{\mathrm{C}}$ [108], ${ }^{\mathrm{d}}$ [40]. Electrolyte temperature ${ }^{\mathrm{a}} 50^{\circ} \mathrm{C},{ }^{\mathrm{c}} 30^{\circ} \mathrm{C}$ and ${ }^{\mathrm{d}} 25^{\circ} \mathrm{C}$.

\begin{tabular}{|c|c|c|c|c|c|c|c|c|}
\hline \multirow[t]{2}{*}{ Inhibitor $/ \mathrm{mol} \mathrm{dm}^{-3}$} & \multirow{2}{*}{$\begin{array}{l}\% \text { inhibition eff. at open-circuit } \\
\% \varphi_{\text {inh }}\end{array}$} & \multirow{2}{*}{\multicolumn{3}{|c|}{$\begin{array}{l}\text { \% discharge efficiency under } \\
\text { galvanostatic discharge } \\
\% \varphi_{\text {dis }} \text { at } j \text { in } \mathrm{mA} \mathrm{cm}^{-2}\end{array}$}} & \multicolumn{4}{|c|}{ Electrode potential during galvanostatic discharge } \\
\hline & & & & & E vs. $\mathrm{H}_{\xi}$ & & & \\
\hline \multicolumn{2}{|l|}{-} & 100 & 200 & 400 & $E_{o c}$ & $E_{100}$ & $E_{200}$ & $E_{400}$ \\
\hline \multirow{2}{*}{\multicolumn{2}{|c|}{ Pure $\mathrm{Al}$ in uninhibitied solution ${ }^{\mathrm{a}}$}} & 70 & 89 & & -1.71 & -1.56 & -1.41 & \\
\hline & \multicolumn{8}{|c|}{ Stannate } \\
\hline $10^{-4} \mathrm{Na}_{2} \mathrm{SnO}_{3}^{\mathrm{a}}$ & -94 & & & & -1.61 & & & \\
\hline $10^{-3} \mathrm{Na}_{2} \mathrm{SnO}_{3}{ }^{\mathrm{a}}$ & 24 & 79 & 95 & & -1.73 & -1.54 & -1.44 & \\
\hline $10^{-2} \mathrm{Na}_{2} \mathrm{SnO}_{3}^{\mathrm{a}}$ & 67 & 63 & 77 & & -1.68 & -1.48 & -1.3 & \\
\hline \multicolumn{9}{|l|}{ Indium hydroxide } \\
\hline $10^{-4} \operatorname{In}(\mathrm{OH})_{3}^{\mathrm{a}}$ & 97 & & 50 & & -1.75 & & -1.6 & \\
\hline $10^{-3} \operatorname{In}(\mathrm{OH})_{3}^{\mathrm{a}}$ & -178 & & & & -1.74 & & & \\
\hline $10^{-2} \operatorname{In}(\mathrm{OH})_{3}^{\mathrm{a}}$ & -195 & 30 & 49 & & -1.73 & -1.65 & -1.55 & \\
\hline $10^{-3} \mathrm{~K}_{2} \mathrm{MnO}_{4}^{\mathrm{a}}$ & 32 & 91 & 99 & & -1.73 & -1.5 & -1.3 & \\
\hline $10^{-3} \mathrm{~K}_{2} \mathrm{MnO}_{4}+10^{-3} \operatorname{In}(\mathrm{OH})_{3}^{\mathrm{a}}$ & -5 & 70 & 87 & 96 & -1.71 & -1.55 & -1.32 & -1.1 \\
\hline $10^{-3} \mathrm{~K}_{2} \mathrm{MnO}_{4}+10^{-2} \operatorname{In}(\mathrm{OH})_{3}^{\mathrm{a}}$ & 26 & 69 & 87 & & -1.7 & -1.4 & -1.1 & \\
\hline $10^{-2} \mathrm{Na}_{2} \mathrm{SnO}_{3}+10^{-3} \operatorname{In}(\mathrm{OH})_{3}{ }^{\mathrm{a}}$ & 80 & 76 & 88 & 96 & -1.72 & -1.55 & -1.4 & -1.1 \\
\hline $10^{-2} \mathrm{Na}_{2} \mathrm{SnO}_{3}+10^{-2} \operatorname{In}(\mathrm{OH})_{3}{ }^{\mathrm{a}}$ & 73 & 79 & 89 & 96 & -1.75 & -1.5 & -1.47 & -1.38 \\
\hline $0.2 \mathrm{M} \mathrm{ZnO}^{\mathrm{d}}$ & 98 & & & & -1.31 & & & \\
\hline \multicolumn{9}{|l|}{ Cationic surfactants } \\
\hline $1.8 \times 10^{-4} \mathrm{CTAB}^{\mathrm{b}}$ & 14 & & & & -1.42 & & & \\
\hline $0.5 \times 10^{-3} \mathrm{CTAC}^{\mathrm{C}}$ & 40 & & & & & & & \\
\hline $2.976 \mathrm{~g} \mathrm{~L}^{-1}$ lupine $\mathrm{b}^{\mathrm{b}}$ & 63 & & & & -1.47 & & & \\
\hline
\end{tabular}

significant for small scale $\mathrm{Al}$-air batteries in the several watts range employing a simple static electrolyte system at ambient temperature upon start-up. If the system is starting from room temperature, an applicable alloy would have to be chosen. If an alloy from Table 3 is selected, external pre-heating of the electrolyte may be feasible to activate the alloy or a run-in time would have to be accommodated for as the electrolyte heats up. Experiments have shown that during discharge the electrolyte temperature will increase from 20 to $60{ }^{\circ} \mathrm{C}$ after at least $1 \mathrm{~h}$ discharge [103].

\subsection{Grain size}

The effect of grain size on the corrosion and anodic behaviour of aluminium alloys in alkaline solutions was not discussed in the above studies. It may be an important point to consider as the grain size of the alloys will vary depending on the duration of the solution heat treatment. A fine-grained structure will have a high density of inter-crystalline areas such as grain boundaries and triple junctions which increase the reactivity of the surface through increased electron activity and diffusion [104]. Passive film formation and adhesion would improve as a result, reducing the alloy's anodic behaviour. Also the enhanced diffusion may reduce the length of time at which surface deposits of the alloying element, formed via the dissolution-deposition mechanism, are retained on the surface. This would dictate whether a particular minimum surface concentration of the reduced metal species is retained on the surface to reach activation [76]. Other factors to consider include the processing route used to manufacture the electrodes, because this leads to microstructural changes, develops alloy texture and introduces internal stresses, which may impart cracks into the passive film [104,105].

\section{Effect of electrolyte additives on an aluminium anode}

Manufacturing super-pure aluminium alloys with trace amounts of elements such as tin and indium is expensive. An alternative method of reducing the corrosion of aluminium in alkaline solutions, without affecting its dissolution characteristics, is to add inhibitors to the electrolyte [32]. They are advantageous because (a) they allow inexpensive scrap aluminium to be used as anodes instead of expensive high-purity aluminium alloys, (b) they increase the overpotential for parasitic hydrogen evolution [10] and (c) inhibition of the cathodic water reduction reaction shifts its open-circuit potential to more negative values [32]. The solution phase inhibitors chosen are typically the same as the elements used to form the high-purity aluminium alloys [32]. Additives can also be added to cause the aluminium hydroxide to form into a crystalline powder form, falling to the bottom of the cell leaving the reaction surface at the anode clear and active [106].

Gallium as an electrolyte additive was found not to be viable as a solution phase inhibitor as it resulted in the rapid corrosion and consumption of the aluminium [32]. Difficulties associated with employing solution phase additives include: (i) electrolyte composition change and (ii) formation of large insoluble precipitates which could block and short-circuit the cells as well as interfere with the performance of the air cathodes and the precipitation kinetics of $\mathrm{Al}(\mathrm{OH})_{3}$ [73].

This section examines the effect of electrolyte additives on the electrochemical behaviour of pure aluminium, of $99.99 \%$ purity or higher, unless otherwise stated. Studies which investigated the effect of additives on commercial grade aluminium alloys have not been included in this review [107].

\subsection{Stannate ion}

Stannate, $\mathrm{SnO}_{3}^{2-}$, has varying effects on the corrosion and dissolution of aluminium in alkaline solutions, depending on the quantity used. Among a range of concentrations in a $4 \mathrm{~mol} \mathrm{dm}^{-3}$ $\mathrm{KOH}$ solution at $50{ }^{\circ} \mathrm{C}, 1 \times 10^{-3} \mathrm{~mol} \mathrm{dm}^{-3} \mathrm{Na}_{2} \mathrm{SnO}_{3}$ was found to be ideal, as it showed discharge efficiencies as high as 95\%, see Table 4 . The tin plated out of the electrolyte onto cathodic sites on the surface of the aluminium inhibiting the water reduction reaction [32]. A concentration of $1 \times 10^{-3} \mathrm{~mol} \mathrm{dm}^{-3} \mathrm{Na}_{2} \mathrm{SnO}_{3}$ also resulted in the least change in anodic behaviour of pure Al under galvanostatic discharge, as indicated in Table 4 [32]. There is no evidence of a well-defined potential range over which the stannate ion exerts an effect on the aluminium, corresponding to the stability range for tin. Comparison with the anodic behaviour of $\mathrm{Al} / \mathrm{Sn}$ binary alloys in 
Table 5

Survey of high-activity gas diffusion electrode designs. CB is carbon black, AB is acetylene black. All designs incorporated a nickel-mesh current collector.

\begin{tabular}{|c|c|c|c|c|c|}
\hline Gas diffusion layer & Catalyst & $\begin{array}{l}\text { Preparation of carbon } \\
\text { supported catalyst }\end{array}$ & $\begin{array}{l}\text { Active layer } \\
\text { composition }\end{array}$ & $I_{L} / \mathrm{mA} \mathrm{cm}^{-2}$ & Reference \\
\hline \multicolumn{6}{|l|}{ Perovskite type } \\
\hline $\mathrm{CB}, 4.7 \mathrm{~m}^{2} \mathrm{~g}^{-1}, 30 \%$ PTFE & $1.9 \mathrm{mg} \mathrm{cm}^{-2} \mathrm{La}_{0.6} \mathrm{Sr}_{0.4} \mathrm{Mn}_{0.8} \mathrm{Fe}_{0.2} \mathrm{O}_{3}$ & Reverse micelle & $\begin{array}{l}\text { KB } 1270 \mathrm{~m}^{2} \mathrm{~g}^{-1} \text {, } \\
\text { 15\% PTFE }\end{array}$ & $\begin{array}{l}500 \mathrm{~mA} \mathrm{~cm} \mathrm{~cm}^{-2} \text { at }-67 \mathrm{mV} \\
\text { vs. } \mathrm{Hg} / \mathrm{HgO} \text {, oxygen flow }\end{array}$ & [191] \\
\hline CB $74 \mathrm{~m}^{2} \mathrm{~g}^{-1}, 15-25 \%$ PTFE & $3.5-9.9 \mathrm{mg} \mathrm{cm}^{-2} \mathrm{La}_{0.6} \mathrm{Ca}_{0.4} \mathrm{CoO}_{3}$ & $\begin{array}{l}\text { Amorphous citrate } \\
\text { precursor }\end{array}$ & $\begin{array}{l}\text { CB } 830 \mathrm{~m}^{2} \mathrm{~g}^{-1} \\
15-25 \% \text { PTFE }\end{array}$ & $\begin{array}{l}3000 \mathrm{~mA} \mathrm{~cm}{ }^{-2} \text { at }-125 \mathrm{mV} \\
\text { vs. } \mathrm{Hg} / \mathrm{HgO} \text { oxygen flow; } \\
166 \mathrm{~mA} \mathrm{~cm}{ }^{-2} \text { at }-125 \mathrm{mV} \\
\text { vs. } \mathrm{Hg} / \mathrm{HgO} \text { air flow }\end{array}$ & [192] \\
\hline $70 \%$ AB, 30\% PTFE & $50 \% \mathrm{La}_{0.6} \mathrm{Ca}_{0.4} \mathrm{CoO}_{3}$ & $\begin{array}{l}\text { Amorphous citrate } \\
\text { precursor }\end{array}$ & $\begin{array}{l}35 \% \text { KB } 1300 \mathrm{~m}^{2} \mathrm{~g}^{-1} \text {, } \\
\text { 15\% PTFE }\end{array}$ & $\begin{array}{l}300 \mathrm{~mA} \mathrm{~cm}{ }^{-2} \text { at }-200 \mathrm{mV} \\
\text { vs. } \mathrm{Hg} / \mathrm{HgO} \text {, air flow }\end{array}$ & [128] \\
\hline 30-50\% carbon, $50-70 \%$ PTFE & $\mathrm{La}_{0.6} \mathrm{Ca}_{0.4} \mathrm{CoO}_{3}$ & $\begin{array}{l}\text { Amorphous citrate } \& \\
\text { drip pyrolysis }\end{array}$ & $\begin{array}{l}\text { Graphite/graphitised } \\
\text { AB, 25\% PTFE }\end{array}$ & $\begin{array}{l}1000 \mathrm{~mA} \mathrm{~cm}^{-2} \text { at }-275 \mathrm{mV} \\
v s . \mathrm{Hg} / \mathrm{HgO} \text {, oxygen flow }\end{array}$ & [193] \\
\hline $70 \%$ CB $47 \mathrm{~m}^{2} \mathrm{~g}^{-1}, 30 \%$ PTFE & $6 \mathrm{mg} \mathrm{cm}^{-2} \mathrm{LaMnO}_{3}$ & Reverse micelle & $\begin{array}{l}85 \% \text { KB } 1270 \mathrm{~m}^{2} \mathrm{~g}^{-1} \text {, } \\
15 \% \text { PTFE }\end{array}$ & $\begin{array}{l}300 \mathrm{~mA} \mathrm{~cm}-2 \text { at }-300 \mathrm{mV} \\
\text { vs. } \mathrm{Hg} / \mathrm{HgO} \text {, air flow }\end{array}$ & [131] \\
\hline $70 \%$ CB $47 \mathrm{~m}^{2} \mathrm{~g}^{-1}, 30 \%$ PTFE & $6 \mathrm{mg} \mathrm{cm}^{-2} \mathrm{LaMnO}_{3}$ & Reverse micelle & $\begin{array}{l}\text { KB } 1270 \mathrm{~m}^{2} \mathrm{~g}^{-1} \text {, } \\
15 \% \text { PTFE }\end{array}$ & $\begin{array}{l}400 \mathrm{~mA} \mathrm{~cm}^{-2} \text { at }-100 \mathrm{mV} \\
\text { vs. } \mathrm{Hg} / \mathrm{HgO} \text {, air flow }\end{array}$ & [194] \\
\hline $70 \%$ CB $47 \mathrm{~m}^{2} \mathrm{~g}^{-1}, 30 \%$ PTFE & $\mathrm{LaMnO}_{3}, 20-30 \mathrm{~nm}$ & NAC-FAS \& milling & $\begin{array}{l}\text { KB } 1270 \mathrm{~m}^{2} \mathrm{~g}^{-1} \text {, } \\
15 \% \text { PTFE }\end{array}$ & $\begin{array}{l}300 \mathrm{~mA} \mathrm{~cm}-2 \text { at }-80 \mathrm{mV} \\
\text { vs. } \mathrm{Hg} / \mathrm{HgO} \text {, air flow }\end{array}$ & [195] \\
\hline $\begin{array}{l}40 \% \text { AB/active carbon } \\
\text { mixture, } 60 \% \text { PTFE }\end{array}$ & $10 \% \mathrm{La}_{0.6} \mathrm{Sr}_{0.4} \mathrm{MnO}_{3}, 20-50 \mathrm{~nm}$ & $\begin{array}{l}\text { Sol-gel \& ultrasonic } \\
\text { dispersion }\end{array}$ & $50 \%$ CB, $40 \%$ PTFE & $\begin{array}{l}324 \mathrm{~mA} \mathrm{~cm}^{-2} \text { at }-200 \mathrm{mV} \\
\text { vs. } \mathrm{Hg} / \mathrm{HgO}\end{array}$ & [196] \\
\hline $70 \%$ CB $47 \mathrm{~m}^{2} \mathrm{~g}^{-1}, 30 \%$ PTFE & $\mathrm{La}_{0.4} \mathrm{Ca}_{0.6} \mathrm{Mn}_{0.9} \mathrm{Fe}_{0.1} \mathrm{O}_{3}, 15 \mathrm{~nm}$ & Reverse micelle & $\begin{array}{l}\text { KB } 1270 \mathrm{~m}^{2} \mathrm{~g}^{-1} \text {, } \\
15 \% \text { PTFE }\end{array}$ & $\begin{array}{l}500 \mathrm{~mA} \mathrm{~cm}{ }^{-2} \text { at }-50 \mathrm{mV} \\
\text { vs. } \mathrm{Hg} / \mathrm{HgO} \text {, oxygen flow }\end{array}$ & [197] \\
\hline \multicolumn{6}{|l|}{ Porphyrin } \\
\hline $65 \%$ Vulcan HT, 35\% PTFE & Co-TMPP & $\begin{array}{l}\text { Sigma Aldrich \& } \\
\text { dispersion } \\
\text { with n-hexane }\end{array}$ & $\begin{array}{l}\text { 70\% Vulcan, } \\
30 \% \text { PTFE }\end{array}$ & $\begin{array}{l}500 \mathrm{~mA} \mathrm{~cm}^{-2} \text { at }-250 \mathrm{mV} \\
\text { vs. } \mathrm{Hg} / \mathrm{HgO} \text {, air }\end{array}$ & [198] \\
\hline 30-50\% carbon, 50-70\% PTFE & СоТРP, $10-80 \mathrm{~nm}$ & $\begin{array}{l}\text { Acetate precursor } \\
\text { method }\end{array}$ & $\begin{array}{l}\text { Vulcan } 254 \mathrm{~m}^{2} \mathrm{~g}^{-1} \\
10-20 \% \text { PTFE }\end{array}$ & $\begin{array}{l}1000 \mathrm{~mA} \mathrm{~cm}{ }^{-2} \text { at }-186 \mathrm{mV} \\
\text { vs. } \mathrm{Hg} / \mathrm{HgO} \text {, oxygen flow }\end{array}$ & [133] \\
\hline \multicolumn{6}{|l|}{ Spinel } \\
\hline $70 \% \mathrm{~EB}, 30 \%$ PTFE & $25 \% \mathrm{LiMn}_{2} \mathrm{Co}_{1} \mathrm{O}_{4}$ & $\begin{array}{l}\text { Amorphous citrate } \\
\text { method }\end{array}$ & $60 \%$ CB, $15 \%$ PTFE & $\begin{array}{l}500 \mathrm{~mA} \mathrm{~cm}{ }^{-2} \text { at }-400 \mathrm{mV} \\
v s . \mathrm{Hg} / \mathrm{HgO} \text {, oxygen flow }\end{array}$ & [199] \\
\hline 70\% EB, 30\% PTFE & $25 \% \mathrm{LiMn}_{1.4} \mathrm{Co}_{0.6} \mathrm{O}_{4}$ & $\begin{array}{l}\text { Amorphous citrate } \\
\text { method }\end{array}$ & $60 \%$ CB, $15 \%$ PTFE & $\begin{array}{l}2500 \mathrm{~mA} \mathrm{~cm}^{-2} \text { at }-300 \mathrm{mV} \\
\text { vs. } \mathrm{Hg} / \mathrm{HgO} \text {, oxygen flow }\end{array}$ & {$[200]$} \\
\hline $40 \%$ AB, $60 \%$ PTFE & $\mathrm{MnCo}_{2} \mathrm{O}_{4}$ & $\begin{array}{l}\text { Nitrate precursor in } \\
\text { microwave oven }\end{array}$ & Acetylene black & $\begin{array}{l}250 \mathrm{~mA} \mathrm{~cm}^{-2} \text { at }-140 \mathrm{mV} \\
\text { vs. } \mathrm{Hg} / \mathrm{HgO} \text {, air }\end{array}$ & [201] \\
\hline \multicolumn{6}{|l|}{ Catalyst mixtures } \\
\hline $40 \%$ Vulcan XC-72, $60 \%$ PTFE & $\begin{array}{l}9.5 \mathrm{mg} \mathrm{cm}^{-2} \mathrm{La}_{0.1} \mathrm{Ca}_{0.9} \mathrm{MnO}_{3} / \\
1.5 \mathrm{mg} \mathrm{cm}^{-2} \text { CoTPP }\end{array}$ & Direct precipitation & $\begin{array}{l}\text { Ketjan Black \& } \\
\text { Vulcan }\end{array}$ & $\begin{array}{l}300 \mathrm{~mA} \mathrm{~cm}^{-2} \text { at }-190 \mathrm{mV} \\
\text { vs. } \mathrm{Hg} / \mathrm{HgO}\end{array}$ & [132] \\
\hline
\end{tabular}

Fig. 3 indicates that this defined potential range, is only observed at $25{ }^{\circ} \mathrm{C}$ and not at elevated temperatures.

At stannate concentrations greater than $1 \times 10^{-2} \mathrm{~mol} \mathrm{dm}^{-3}$, tin plating on the aluminium may give rise to dendritic growths which would short-circuit the battery or damage any electrolyte circulation system $[50,75]$. The stannate interferes with electrolyte management by making it difficult to maintain the required electrolyte concentration due to the precipitation of $\mathrm{Sn}$ in insoluble oxides [74]. It can also retard the growth of aluminium hydroxide crystals reducing the efficiency of any regenerative crystalliser unit $[50,73,75]$. An aluminium-air cell using stannate as an inhibitor in a $7.5 \mathrm{~mol} \mathrm{dm}^{-3} \mathrm{KOH}$ solution had an energy density of $106 \mathrm{~W} \mathrm{~h} \mathrm{~kg}^{-1}$ [62], which is approximately one-quarter of the energy density of commercial Al-air cells.

\subsection{Indate ion}

Additions of $\operatorname{In}(\mathrm{OH})_{3}$ are beneficial for enhancing the anodic behaviour of pure aluminium as shown in Table 4, with $1 \times 10^{-2} \mathrm{~mol} \mathrm{dm}^{-3} \mathrm{In}(\mathrm{OH})_{3}$ inducing the most negative potentials at a given discharge current. In a fashion to $\mathrm{Al} / \mathrm{In}$ alloys, indium hydroxide additives exerted an influence over a defined potential range corresponding to its region of stability. Within this potential region, indium plated out of the electrolyte onto the aluminium surface, helping to break down the passive hydroxide layer to promote oxidation of the underlying aluminium. $\operatorname{In}(\mathrm{OH})_{3}$ electrolyte additions aggravated the corrosion of the pure aluminium, compared to its behaviour in an uninhibited electrolyte, giving negative inhibition efficiencies and low discharge efficiencies, as shown in Table 4 [32]. This aggravated corrosion was due to the rate of hydrogen evolution being much faster reaction on indium than on aluminium [32].

Synergistic effects have been demonstrated among solution phase inhibitors. One example includes $1 \times 10^{-2} \mathrm{~mol} \mathrm{dm}^{-3} \mathrm{Na}_{2} \mathrm{~S}-$ $\mathrm{nO}_{3}$ and $1 \times 10^{-2} \mathrm{~mol} \mathrm{dm}^{-3} \mathrm{In}(\mathrm{OH})_{3}$, combining the corrosion inhibiting effect of $\mathrm{Na}_{2} \mathrm{SnO}_{3}$ and the dissolution promoting effect of $\operatorname{In}(\mathrm{OH})_{3}$. This pair induced a high inhibition efficiency of $73 \%$ at open-circuit and discharge efficiencies as high as $96 \%$ (Table 4). The results of galvanostatic discharge tests in Table 4 show that they also shifted the potential of pure aluminium to more negative values over a current density range of $0-400 \mathrm{~mA} \mathrm{~cm}^{-2}$ [32]. A combination of $1 \times 10^{-3} \mathrm{~mol} \mathrm{dm}^{-3} \mathrm{~K}_{2} \mathrm{MnO}_{4}$ with $1 \times 10^{-3} \mathrm{~mol} \mathrm{dm}^{-3} \mathrm{In}(\mathrm{OH})_{3}$ in $4 \mathrm{~mol} \mathrm{dm}^{-3} \mathrm{KOH}$ was not as effective at inhibiting the open-circuit corrosion or at reducing the anodic electrode overpotential.

\subsection{Cationic surfactants}

Evolution of hydrogen arises from water reduction at cathodic sites on the aluminium surface. Cationic surfactants could inhibit this reaction by blocking the cathodic sites on the aluminium [108]. One such cationic surfactant, cetyltrimethylammonium bromide (CTAB) weakly inhibited the corrosion of $99.6 \%$ aluminium in $2 \mathrm{~mol} \mathrm{dm}{ }^{-3} \mathrm{NaOH}$, with only $14 \%$ inhibition efficiency at opencircuit, see Table 4 [109]. In addition, the CTAB restricted the anodic oxidation of the aluminium by adsorbing at the aluminium/ alkaline solution interface reducing the active area [109]. A similar 
inhibitor, cetyltrimethylammonium chloride (CTAC), tested in the concentration range, $0.15-1.7 \mathrm{mmol} \mathrm{dm}^{-3}$, was also poor at inhibition of the open-circuit corrosion of $99.95 \% \mathrm{Al}$ in $1.5 \mathrm{~mol} \mathrm{dm}^{-3} \mathrm{NaOH}$ [108]. The open-circuit inhibition efficiency for $0.5 \times 10^{-3} \mathrm{~mol} \mathrm{dm}{ }^{-3} \mathrm{CTAC}$ was $40 \%$. In a similar manner to CTAB, the CTAC inhibited the anodic discharge of aluminium [108].

\subsection{Zinc oxide}

The addition of zinc oxide, in a concentration range of 50$600 \times 10^{-3} \mathrm{~mol} \mathrm{dm}^{-3}$, was investigated as a corrosion inhibitor for $99.9995 \% \mathrm{Al}$ in $4 \mathrm{~mol} \mathrm{dm}^{-3} \mathrm{KOH}$, under open-circuit conditions $[40,67,110]$. A maximum inhibition efficiency of $97.5 \%$ was recorded via a hydrogen collection method with a concentration of $0.2 \mathrm{~mol} \mathrm{dm}^{-3} \mathrm{ZnO}$ (Table 4) [40]. The zinc deposited on the aluminium surface, increasing the overpotential for hydrogen evolution. The zinc deposit shifted the anodes open-circuit potential in the positive direction, from -1.7 to $-1.3 \mathrm{~V} v \mathrm{~s}$. $\mathrm{Hg} / \mathrm{HgO}$ because the electrode potential of zinc is more positive than that of aluminium [40,67]. The anodic polarisation curve for $99.9995 \%$ aluminium in a $200 \times 10^{-3} \mathrm{~mol} \mathrm{dm}{ }^{-3}$ zincated solution shows a peak at -1.07 vs. $\mathrm{Hg} / \mathrm{HgO}$. This is due to the oxidation of the zinc deposit in addition to the oxidation of the aluminium. The current peak indicates the point at which all of the zinc had re-dissolved back into the electrolyte and the behaviour returned to that of pure aluminium.

\subsection{Plant extracts}

Plant extracts are being considered as a corrosion inhibitor for aluminium in alkaline solutions as a replacement of toxic chemicals widely used in industry and to reduce the operating cost [109]. Lupine seed extract was found to inhibit the open-circuit corrosion of a $99.6 \% \mathrm{Al}$ alloy in $2 \mathrm{~mol} \mathrm{dm}^{-3} \mathrm{NaOH}$ by $62 \%$, due to adsorption of its active ingredient onto the alloy surface and reducing the active area [109]. However, it also impeded the anodic discharge of the aluminium.

\section{The air (gas diffusion) electrode}

The air cathode (often a gas diffusion electrode) is one of the most expensive components of a metal-air battery and is largely responsible for determining the cell performance [27,111]. Air cathode technology has been reviewed for PEM fuel cell [112,113], metal-air cell [111,114-117] and alkaline fuel cell applications $[118,119]$, and will not be considered in detail here.

The high current densities attainable with the aluminium alloys $\left(600 \mathrm{~mA} \mathrm{~cm}^{-2}\right)$, identified in Table 3 , make the aluminium-air battery versatile for a wide-range of applications depending on what electrocatalyst is selected. Should one of the inexpensive, high-activity catalysed air electrodes shown in Table 5 be chosen, then the aluminium-air battery could be used for a short-discharge high-power density application. It would be limited to a shortdischarge owing to the poor durability of many high-activity catalysts, such as $\mathrm{LaMnO}_{3}$ [111]. Reviewing the design of the highactivity electrodes in Table 5 shows they all have a doublelayered structure of gas diffusion and active layers laminated with a nickel-mesh current collector $[113,120]$. The ratio of carbon/ binder in the respective layers is very similar across the electrodes, forming a bimodal pore network to optimise the wetting of the electrodes without flooding and impeding oxygen diffusion [121125]. The degree of porosity is highly dependent on the sintering times and lamination pressures used during manufacture [126]. The high-activity of the perovskite electrodes is in part due to the promotion of the direct four-electron oxygen reduction as well as catalytically decomposing the peroxide formed at the carbon $[125,127]$. The resistance associated with peroxide diffusion from the carbon to the catalyst can be minimised by taking advantage of a high surface area carbon $\left(1200 \mathrm{~m}^{2} \mathrm{~g}^{-1}\right)$ in the active layer [128]. Some of the highest current densities (upwards of $3000 \mathrm{~mA} \mathrm{~cm}^{-2}$ ) were attainable when pure oxygen was used as the reactant instead of air, while elevated pressures will also have a similar effect [129,130].

The catalyst preparation route is key to the activity of the electrodes shown in Table 5. For example a reverse micelle preparation of perovskites compared to an amorphous malate precursor route achieves a higher dispersion of catalyst on the carbon support and perhaps better catalyst utilisation [131]. The synthesis method will also influence the surface area of the catalyst [132]. In the case of the porphyrins a subsequent heat treatment of the catalyst is required to enhance their activity and stability [133-136]. A reduction in surface area of the carbon support following heat treatment necessitates the use of additional un-heat treated carbon in the active layer to maintain high electrode porosity [133]. Clearly there is great complexity in the design of a high-activity gas diffusion electrode.

In terms of high-energy density applications, manganese oxide has received increased attention due to its high chemical stability as well as low cost and toxicity and high catalytic activity [120,137]. The oxygen reduction reactivity of $\mathrm{MnO}_{x}$ in a coin-type Al-air cell has been compared against that of platinum for galvanostatic discharge at $0.4 \mathrm{~mA}$ using aluminium powder as the anode [137]. The choice of electrolyte, a $\mathrm{KOH} /$ ethanol mixture for this comparison was not appropriate because ethanol is oxidised by platinum to form carbon dioxide $[118,138]$. The discharge density for the button cell with the $\mathrm{MnO}_{x}$ catalyst was $512 \mathrm{~W} \mathrm{~h} \mathrm{~kg}^{-1}-\mathrm{Al}$, which is a fraction of the theoretical specific energy of $8100 \mathrm{~W} \mathrm{~h} \mathrm{~kg}-1-\mathrm{Al}$ of an aluminium anode [137].

Some of the mixed metal-oxide catalysts such as the perovskites are electrically insulating and so the carbon support is used to enhance conductivity. This addresses an area of development in gas diffusion electrodes aimed at minimising the voltage drop associated with the transfer of electrons to the reaction site. At present, gas diffusion electrodes are manufactured by pressing a carbon/ catalyst mixture in between the pores of a metal mesh. This means that the catalyst is not in direct contact with the metal mesh current collector, so there is an associated voltage drop. The ohmic losses associated with the gas diffusion electrode would be reduced by directly bonding the catalyst to the metal mesh current collector $[139,140]$. Electrodeposition of catalysts such as, platinum [141,142] or manganese oxide [143-145], is seen as a feasible way of achieving this $[142,146]$.

\section{Future prospects for aluminium-air batteries}

\subsection{Identification of new aluminium alloy anodes via combinatorial chemistry approaches}

Manufacture and electrochemical testing of super-pure aluminium alloys with varying compositions is an expensive and time-consuming process. Combinatorial chemistry would allow the simultaneous synthesis and screening of a large number of alloys under identical conditions relevant to the aluminium-air environment. This technique is growing in popularity to optimise the composition of materials having specific physical or chemical properties [147]. Using this technology, a $10 \times 10$ array of individually addressable aluminium alloy electrodes could be fabricated onto a silicon nitride capped silicon wafer in a high-throughput physical vapour deposition system. The array would contain a gradient of varying aluminium alloy composition [147,148]. 
Screening would involve carrying out simultaneous half-cell tests on each of the Al alloy electrodes [147]. This would allow identification of the alloying elements, either in binary or ternary alloys that enhance the anodic behaviour of aluminium in alkaline solutions at different temperatures, ranging from 20 to $60{ }^{\circ} \mathrm{C}$. This is important since previous published research has focused on identifying alloys suitable for use at $60{ }^{\circ} \mathrm{C}$. A similar high-throughput screening technique has been used for the evaluation of micro zinc-air [149] and tin-air cells [150].

\subsection{Three-dimensional aluminium alloy anodes}

A three-dimensional aluminium electrode is advantageous to increase the active surface area and hence working current [45]. Various forms of high surface area aluminium exist including foams, meshes and honeycombs [151]. Commercial suppliers of 3-D aluminium metal include: (a) ERG Materials and Aerospace Corporation supply aluminium 6101 foams, (b) COREX, who supply 3003 and 5052 aluminium honeycomb and (c) M-Pore who supply 99\% aluminium foam [152]. A comprehensive list of aluminium foam suppliers is available [153].

One method to fabricate a 3-D aluminium macroporous electrode includes the replication process $[154,155]$. This consists of a pressure filtration technique where a solid material such as $\mathrm{NaCl}$ particles is used as a pore shaping template. Molten aluminium is then poured under pressure of $1 \mathrm{MPa}$ into the porous $\mathrm{NaCl}$ template and allowed to cool down. The template is subsequently removed by dissolution. There may be difficulty maintaining the high-purity of the aluminium alloy during the manufacture of the foam via the replication technique [155]. Another 3-D anode design is aluminium nanorods, 30-90 $\mathrm{nm}$ diameter, 1-2 $\mu \mathrm{m}$ length, produced by chemical vapour deposition [156]. Prototype aluminium-air button cells (diameter, $20 \mathrm{~mm}$ ) employing the 99.99\% pure aluminium nanorods and an air cathode consisting of $\mathrm{La}_{0.6} \mathrm{Ca}_{0.4} \mathrm{CoO}_{3}$ perovskite catalyst had an energy density of $458 \mathrm{~W} \mathrm{~h} \mathrm{~kg}^{-1}$ at a very low discharge current of $0.7 \mathrm{~mA} \mathrm{~cm}^{-2}$. This is superior to that of a similar cell using $99.99 \%$ aluminium powder as the anode $\left(236 \mathrm{~W} \mathrm{~h} \mathrm{~kg}^{-1}\right)$. The larger surface area of the Al nanorods allowed them to deliver more current at a given current density compared to the Al powder. The use of granular $\mathrm{Al}, 8-$ $12 \mathrm{~mm}$ in diameter, as a high surface area anode has also been explored [157]. As the gas diffusion electrode is the limiting component of the battery, a high surface area aluminium anode is only beneficial if it is paired with a similarly high surface area air cathode.

\subsection{Anionic membranes}

Researchers have explored the use of anionic membranes in aluminium-air batteries to restrict the amount of water making contact with the aluminium surface to reduce the parasitic corrosion reaction. One novel approach employed a polymer mixture of polyacrylic acid, PAA encapsulating particles of aluminium powder (11.5-45 $\mu \mathrm{m})$ and facilitating hydroxyl ion conduction [158]. This technique meant that the reaction product, $\mathrm{Al}(\mathrm{OH})_{3}$, remained mostly entrapped by the PAA, helping to maintain electrolyte conductivity throughout the discharge. The energy density of an $\mathrm{Al}-$ air cell constructed with this anode was very low at $199 \mathrm{~W} \mathrm{~h} \mathrm{~kg}^{-1}$-Al. Anion exchange membranes have also been used as a solid polymer electrolyte at the interface between the electrolyte and the air electrode [114]. Two of the functions of this membrane were to prevent the $\mathrm{Al}(\mathrm{OH})_{3}$ clogging the pores of the air cathode and to prevent neutralisation of the alkaline electrolyte by carbon dioxide.

\subsection{Gel and solid polymer electrolytes}

A potassium hydroxide solution gelled with hydrophonics gel (HPG) has been used as an electrolyte for an aluminium-air cell in order to trap the solution and minimise any electrolyte leakage [159]. The energy density was very low at $183 \mathrm{~W} \mathrm{~h} \mathrm{~kg}^{-1}$-Al due to the extremely high resistance of the gel $(11.1 \Omega)$ restricting the discharge current density to below $10 \mathrm{~mA} \mathrm{~cm}^{-2}$, the use of a $95 \mathrm{wt} \%$ pure anode and anode passivation by a layer of $\mathrm{Al}(\mathrm{OH})_{3}$ [159]. The conductivity of gel electrolytes would need to be improved in order for this system to be viable. In another $\mathrm{Al}-$ air cell design an alkaline membrane synthesised from polyvinyl alcohol (PVA) and polyacrylic acid polymer were used as solid polymer electrolyte. A $\mathrm{KMnO}_{4}$ catalysed air electrode formed the cathode and 99.99\% Al plate the anode. The cell's discharge performance was extremely poor with a peak power density of $1.2 \mathrm{~mW} \mathrm{~cm}^{-2}$ at a low current density of $1.2 \mathrm{~mA} \mathrm{~cm}^{-2}$ due to passivation of the aluminium surface by the discharge product [160]. Gel and solid polymer electrolytes have low solubility for $\mathrm{Al}(\mathrm{OH})_{4}^{-}$ions meaning that during anodic discharge the $\mathrm{Al}(\mathrm{OH})_{3}$ cannot dissolve into the electrolyte to form aluminate. The conductivity of these electrolytes is also insufficient to replenish the $\mathrm{OH}^{-}$ions consumed at the electrode surface, resulting in passivation of the aluminium.

\subsection{Mixed electrolytes and alternative solvents}

The aluminium anode in aqueous solutions undergoes selfdischarge with the production of a large amount of hydrogen gas, reaction (4). The solvent water, with its high protic activity, is largely responsible for the large corrosion rate of the aluminium anode in alkaline aqueous solutions [161]. The substitution with an aprotic solvent, that neither donates nor accepts $\mathrm{H}^{+}$ions, may effectively inhibit the corrosion of aluminium.

\subsubsection{Alcohols}

Alcohols used to form both aqueous and non-aqueous alkaline $\mathrm{KOH}$ solutions for aluminium corrosion tests include methanol [162,163], ethanol [164] and propanol [165]. Without any water, there was no hydrogen evolution from the surface of the aluminium in these alkaline alcohol solutions. The open-circuit corrosion current density was extremely low at $0.0976 \mathrm{~mA} \mathrm{~cm}^{-2}$ in a $4 \mathrm{~mol} \mathrm{dm}^{-3} \mathrm{KOH}$ solution at $25^{\circ} \mathrm{C}$ [164]. These solutions almost completely inhibited the oxidation of aluminium as replacing water with the other solvents decreases the ionic conductivity of the electrolyte and the hydration of the surface product layer $[161,162]$. The rate of oxidation of the aluminium was improved upon mixing the alkaline alcohol solutions with water, although still inferior to the performance in a $100 \%$ aqueous solution. Perhaps the dissolution of an aluminium alloy instead of $99.9995 \%$ pure aluminium in these tests may not be as inhibited by these electrolyte mixtures, but that is yet to be determined.

The suitability of alcohols as electrolytes in $\mathrm{Al}$-air batteries depends on their stability in contact with the catalysed air electrode. A platinum catalysed air electrode would be unsuitable for use with methanol or ethanol electrolytes, as they are oxidised by platinum releasing carbon dioxide gas $[118,138]$. Alternative catalysts, such as tungsten carbide-silver composite $\left(\mathrm{Ag}-\mathrm{W}_{2} \mathrm{C} / \mathrm{C}\right)$ [166] and $\mathrm{La}_{0.6} \mathrm{Ca}_{0.4} \mathrm{CoO}_{3}$ perovskite have been successfully used for the reduction of oxygen in alkaline alcohol/water mixtures [156].

\subsubsection{Ionic liquid electrolytes}

As mentioned earlier, aluminium-air batteries are primary sources of energy because aluminium cannot be electrodeposited from aqueous solutions due to its negative standard potential leading to hydrogen evolution before aluminium deposition can 


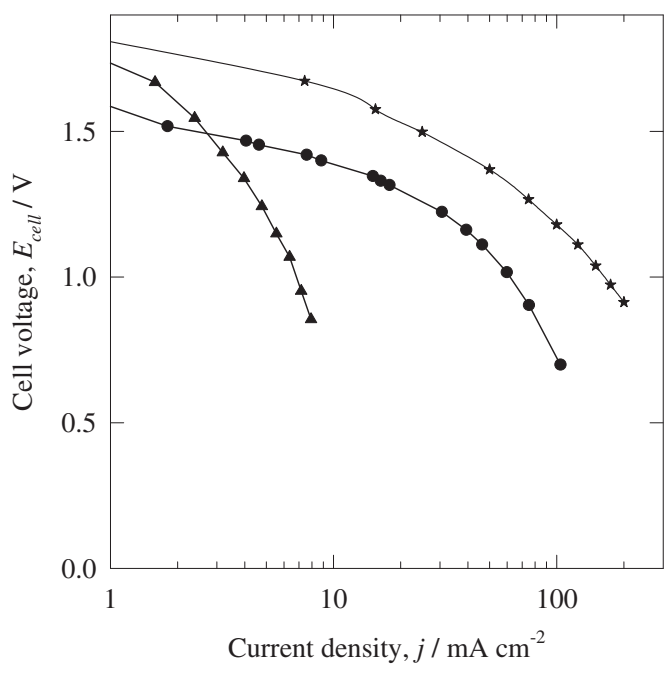

Fig. 9. Comparison of performance data for some Al-air cells. Cell potential difference versus current density curves. The distinguishing features of each of the systems is: $\boldsymbol{\Delta}$ Gel-electrolyte [159], • Bipolar $\mathrm{Al}-$ air cell with 99.99\% $\mathrm{Al}$ [52], $\star \mathrm{Al}-\mathrm{O}_{2}$ system with flowing electrolyte [63].

occur at the negative electrode [25,26]. A suitable electrolyte for a rechargeable aluminium-air battery is one that is aprotic such as ionic liquids and electrolytes based on organic aprotic solvents [26,167]. The disadvantages of organic solvents, such as tetrahydrofuran, include narrow electrochemical window, low electrical conductivity and high volatility and flammability [168]. Details and current challenges with ionic liquids are briefly discussed below. More detailed reviews covering the history and use of ionic liquids can be found elsewhere [169-172].

Research into ionic liquids for metal-air batteries has received enormous investment. For example, in November 2009, the U.S. Department of Energy awarded a $\$ 5.13$ million research grant to Fluidic Energy towards the development of a metal-air battery using an ionic liquid electrolyte [173]. Ionic liquids are room temperature molten salts, composed mostly of organic ions that can be used as solvents for the electrodeposition of metals or as the electrolyte for batteries [170]. An ionic liquid electrolyte is advantageous compared to aqueous electrolytes, as aluminium is not prone to the parasitic hydrogen generation reaction [174].

Chloroaluminate ionic liquids are considered to be the first generation of ionic liquids used for the electrodeposition of aluminium $[25,175,176]$. These are prepared by combining highly hygroscopic $\mathrm{AlCl}_{3}$ with a suitable organic chloride such as $N$-butylpyridinium chloride (N-BPC) and 1-ethyl-3methylimidazolium chloride (EMIC) [177]. Several researchers have explored the use of chloroaluminate ionic liquids as electrolytes for aluminium batteries [167,178]. One drawback is difficulty with preparation due to the highly exothermic reaction between 1ethyl-3-methylimidazolium chloride (EMIC), and $\mathrm{AlCl}_{3}$, making them expensive $[167,179,180]$. Other chloroaluminate ionic liquids such as trimethylphenyl ammonium chloride (TMPAC)- $\mathrm{AlCl}_{3}$ are easy and inexpensive to prepare in a relatively high state of purity since TMPAC is commercially available in high-purity [181]. The conductivity of the $\mathrm{AlCl}_{3} / \mathrm{EMIC}$ ionic liquids is significantly inferior to that of aqueous solutions at $0.017 \mathrm{~S} \mathrm{~cm}^{-1}$ [179] compared to $0.7 \mathrm{~S} \mathrm{~cm}^{-1}$ for $7 \mathrm{~mol} \mathrm{dm}^{-3} \mathrm{KOH}$ at $30^{\circ} \mathrm{C}$ [56]. Due to their hygroscopic nature, chloroaluminate ionic liquids must be handled under an inert-gas atmosphere or at least under dry air $[25,168,169]$. This rules them out for use as an electrolyte in aluminium-air batteries unless the battery could be sealed and an $\mathrm{O}_{2}$-permeating membrane placed on the external surface of the air cathode to prevent moisture, from the air, ingressing into the cell [182]. Cycling of ionic liquid $\mathrm{AlCl}_{3} / \mathrm{EMIC}$ ionic liquid resulted in changes in electrolyte composition, which limited the cyclability of the deposited aluminium [178].

An alternative to the chloroaluminate ionic liquids is air and water stable ionic liquids such as 1-ethyl-3-methylimidazolium bis(trifluoromethylsulfonyl)amide ([EMIm]TFSI), 1-butyl-1-met hylpyrrolidinium bis(trifluoromethylsulfonyl)imide ([BMP]TFSI), [(Trihexl-tetradecyl)phosphonium] bis(trifluoromethylsulfonyl) imide $\left(\mathrm{P}_{14,6,6,6}\right.$ TFSI $)[25,183]$ and 1-butyl-3-methylimidazolium tetrafluoroborate, [BMIm]TFB [161]. Mixing these liquids with $\mathrm{AlCl}_{3}$ and following successive aluminium deposition and stripping cycles, charge efficiencies of $100 \%, 4 \%$ and $87 \%$ respectively were recorded at $25{ }^{\circ} \mathrm{C}$ [25]. [EMIm]TFSI was superior to the other two because its lower viscosity allowed it to deliver a higher peak discharge current density of $12 \mathrm{~mA} \mathrm{~cm}^{-2}$ compared to $0.1 \mathrm{~mA} \mathrm{~cm} \mathrm{~m}^{-2}$ for [BMP]TFSI and $0.4 \mathrm{~mA} \mathrm{~cm}{ }^{-2}$ for $\mathrm{P}_{14,6,6,6}$ TFSI at $25{ }^{\circ} \mathrm{C}$ [25]. Although these ionic liquids are still novel and expensive, their cost should come down if they go into large-scale production for aluminium electrodeposition [171].

The charge-discharge behaviour of an air electrode in the ionic liquid, TMPATFSI (Trimethyl-n-propylammonium bis(trifluoromethylsulfonyl) imide), has been investigated [184]. The air electrode was a mixture of nickel particles bound with PTFE particles, with one side in contact with the electrolyte and the other open to the air. The mechanism of oxygen reduction proceeds via a reversible $1 \mathrm{e}^{-}$step to form the superoxide ion, $\mathrm{O}_{2}^{--}[185,186]$. In practical terms a one-electron transfer step at the air cathode will limit the power density of rechargeable ionic liquid aluminium-air batteries.

Several novel developments in aluminium-air battery research have been discussed above. The performance of these systems, such as the gel-electrolyte based one, in terms of maximum discharge current density and energy density is far inferior to the conventional $\mathrm{Al}$-air cell design employing a re-circulating electrolyte, as indicated in Fig. 9. Of the systems, a maximum of $3900 \mathrm{~W} \mathrm{~h} \mathrm{~kg}^{-1}$-Al at a discharge current density of $50 \mathrm{~mA} \mathrm{~cm}{ }^{-2}$ was delivered by an aluminium-oxygen system incorporating an $\mathrm{Al} / \mathrm{Mn} / \mathrm{In} / \mathrm{Mg}$ alloy [63]. This cell delivered reasonable cell potential differences up to current densities of $200 \mathrm{~mA} \mathrm{~cm}{ }^{-2}$. The other flowing electrolyte system shown in Fig. 9, the bipolar design, could not be discharged at such high current densities because it used $99.99 \% \mathrm{Al}$ as the anode which was inferior to the $\mathrm{Al} / \mathrm{Mn} / \mathrm{In} / \mathrm{Mg}$ alloy used by the other system [52].

\section{Conclusions}

1. The corrosion and oxidation of pure aluminium in alkaline solutions is dependent on a number of variables including the electrolyte properties: temperature and its type, its flow rate and concentration, along with the purity of the aluminium. Pure aluminium in an uninhibited alkaline solution oxidises at a high overpotential because of a passive hydroxide layer and has a low discharge efficiency because of a parasitic reaction involving the reduction of water.

2. Alloying aluminium with particular elements or adding inhibitors to the electrolyte can reduce the self-corrosion and enhance its oxidation rate. Properties of a suitable alloying element include: (i) a low melting temperature to form a solid solution alloy with aluminium, (ii) solubility with aluminium, (iii) a higher nobility than aluminium in the electrochemical series, (iv) solubility in the electrolyte and (v) a high hydrogen overpotential.

3. The electrochemistry of the alloys is determined by the electrochemistry of the alloying element and is highly dependent on the electrolyte temperature. An alloy that has enhanced anodic behaviour at $60{ }^{\circ} \mathrm{C}$ may not display this enhanced behaviour at $25{ }^{\circ} \mathrm{C}$. Similarly an alloy with poor corrosion 
behaviour at $60{ }^{\circ} \mathrm{C}$, may not yield such poor behaviour at a lower temperature. There is a shortage of anodic polarisation, galvanostatic discharge and corrosion data for aluminium alloys in alkaline solutions at $25^{\circ} \mathrm{C}$.

4. Alloys desirable at $60{ }^{\circ} \mathrm{C}$ that exhibited extremely high anodic currents, upwards of $600 \mathrm{~mA} \mathrm{~cm}^{-2}$ at potentials of $-1.64 \mathrm{Vvs} . \mathrm{Hg}$ $\mathrm{HgO}$ and discharge efficiencies greater than $90 \%$ include $\mathrm{Al} / 0.5 \%$ $\mathrm{Mg} / 0.07 \% \mathrm{Sn}$, known as EB50V, and $\mathrm{Al} / 0.84 \mathrm{Mg} / 0.13 \mathrm{Mn} / 0.11 \mathrm{In}$. More detailed experimental study is required on the effect of other alloying elements such as antimony, bismuth, cadmium and zinc in quantities closer to their solubility limit in aluminium.

5. The rationale behind the choice of electrolyte inhibitor is similar to that of alloying elements. A suitable inhibitor pair is $10 \mathrm{mmol} \mathrm{dm}^{-3} \mathrm{Na}_{2} \mathrm{SnO}_{3}+10 \mathrm{mmol} \mathrm{dm}^{-3} \mathrm{In}(\mathrm{OH})_{3}$ for use at $50{ }^{\circ} \mathrm{C}$. Many studies of electrolyte inhibitors have evaluated effectiveness solely on its inhibition efficiency at open-circuit. Further work should be carried out on additions like $\mathrm{ZnO}$, to elucidate their effectiveness at inhibiting the hydrogen evolution under discharge. Investigations can explore synergies between corrosion inhibiting additives such as cetyltrimethylammonium bromide and activating additives such as indium hydroxide. The solubility limit of inhibitors in alkaline solutions needs to be characterised to determine their desired concentration.

6 . The design of gas diffusion electrodes plays as an important role as the material electrochemistry. A step-change in the design of gas diffusion electrodes can be achieved by binding the electrocatalyst directly to the metal mesh current collector to minimise resistance to transfer of electrons to the reaction sites.

\section{Future developments}

Finally, likely future developments in alkaline aluminium-air batteries are considered. Although several alloys have been identified with lower corrosion currents compared to pure aluminium, their rate of self-corrosion particularly at open-circuit is still of the order of $10 \mathrm{~mA} \mathrm{~cm}^{-2}$ which is unacceptable when compared with that shown by zinc (ca. $0.1 \mathrm{~mA} \mathrm{~cm}^{-2}$ ). This problem of self-corrosion coupled with the high cost for manufacture of high-purity aluminium alloys excludes aluminium-air batteries for use as commercial portable batteries employing a static electrolyte design. The issue of cost can be addressed by reviewing the literature on the corrosion and anodic behaviour of commercially available alloys in alkaline solutions and comparing it with that of the high-purity alloys identified in this review. The challenge of open-circuit self-corrosion can be overcome by integrating an $\mathrm{Al}$-air battery with a flowing electrolyte system, where the electrolyte can be stored externally to the cell when not in use, although operational hydrogen management would still be required. The irreversibility of the aluminium oxidation reaction means that a flowing electrolyte system may be less favourable compared to an electronically rechargeable battery. Currently the knowledge gained in trying to minimise the volume of evolved hydrogen from the alloy surface is being used to design aluminium alloys as portable sources of hydrogen, to overcome the technical challenges associated with hydrogen transport for fuel cell applications. Al-air batteries have also received interest for niche military applications requiring an expendable, light-weight high-power density battery such as those required in a micro-unmanned aerial vehicle.

\section{References}

[1] D.R.P. Egan, C.TJ. Low, F.C. Walsh, J. Power Sources 196 (2011) 5725

[2] E.I. Shkolnikov, A.Z. Zhuk, M.S. Vlaskin, Renew. Sust. Energ. Rev. 15 (2011) 4611

[3] Q. Li, N.J. Bjerrum, J. Power Sources 110 (2002) 1.
[4] Technology roadmap electric and plug-in hybrid electric vehicles, http:// www.iea.org/papers/2009/EV_PHEV_Roadmap.pdf, (accessed 07.08.12).

[5] J.A. Hunter, G.M. Scamans, J. Sykes, in: Power Sources 13: International Power Sources Symposium, vol. 17, 1991, p. 193.

[6] Alkaline aluminium-air fuel cell power supply system APS 100, http:// altekfuel.com/userfiles/File/SDS_APS100_12-24_V-04.pdf, (accessed 07.08.12)

[7] www.yardney.com/AluPower/alupower.html, [accessed 07.08.12]

[8] R.K. Morris, G.A. Ottewill, B.D. Barker, F.C. Walsh, Int. J. Eng. Educ. 18(2002) 379

[9] M. Pourbaix, Atlas of Electrochemical Equilibria in Aqueous Solutions, Pergamon Press, 1966.

[10] M.L. Doche, J.J. Rameau, R. Durand, F. Novel-Cattin, Corros. Sci. 41 (1999) 805

[11] J. Bernard, M. Chatenet, F. Dalard, Electrochim. Acta 52 (2006) 86.

[12] R.D. Armstrong, V.J. Braham, Corros. Sci. 38 (1996) 1463.

[13] B.M.L. Rao, G.M. Scamans, in: Proc. 10th International Seminar on Primary and Secondary Battery Technology Applications, Deerfied Beach, Florida, 1993.

[14] R.P. Hamlen, W.H. Hoge, J.A. Hunter, W.B. O'Callaghan, IEEE AES Syst. Mag. 11 (1991).

[15] T.A. Dougherty, A.P. Karpinski, J.H. Stannard, W. Halliop, S. Warner, in: Energy Conversion Engineering Conference, 1996. IECEC 96, Proceedings of the 31st Intersociety, vol. 1172, 1996, pp. 1176-1180.

[16] H. Wu, Nanjing, in: World Non-grid-connected Wind Power and Energy Conference (WNWEC), 2010, IEEE, 2010.

[17] C.D.S. Tuck, Modern Battery Technology, Ellis Horwood, 1991.

[18] N. Fitzpatrick, G. Scamans, in: New Scientist, 1986, pp. 34-37.

[19] H.Z. Wang, D.Y.C. Leung, M.K.H. Leung, M. Ni, Renew. Sust. Energ. Rev. 13 (2009) 845.

[20] C.A.C. Sequeira, Environmental Oriented Electrochemistry, Elsevier, 1994.

[21] S. Yang, H. Knickle, J. Power Sources 112 (2002) 162.

[22] X. Zhang, S.H. Yang, H. Knickle, J. Power Sources 128 (2004) 331.

[23] E. Lemieux, W.H. Hartt, K.E. Lucas, in: Corrosion NACE International, Houston, Texas (2001)

[24] J. Zhang, M. Klasky, B.C. Letellier, J. Nucl. Mater. 384 (2009) 175.

[25] S.Z.E. Abedin, E.M. Moustafa, R. Hempelmann, H. Natter, F. Endres, ChemPhysChem 7 (2006) 1535

[26] M. Gálová, Surf. Technol. 11 (1980) 357.

[27] D. Linden, T.B. Reddy, Handbook of Batteries, third ed., McGraw-Hill, 2001

[28] M. Nestoridi, D. Pletcher, R.J.K. Wood, S. Wang, R.L. Jones, K.R. Stokes, I. Wilcock, J. Power Sources 178 (2008) 445.

[29] S.-I. Pyun, S.-M. Moon, J. Solid State Electrochem. 4 (2000) 267.

[30] S. Real, M. Urquidi-MacDonald, D.D. MacDonald, J. Electrochem. Soc. 135 (1988) 1633

[31] D.H. Scott, The Effect of Manganese Additions on the Performance of Aluminium Air Battery Anode Alloys, Lawrence Livermore National Laboratory, May 5, 1982.

[32] D.D. MacDonald, C. English, J. Appl. Electrochem. 20 (1990) 405

[33] D. Chu, R.F. Savinell, Electrochim. Acta 36 (1991) 1631

[34] O.R. Brown, J.S. Whitley, Electrochim. Acta 32 (1987) 545.

[35] M. Boinet, J. Bernard, M. Chatenet, F. Dalard, S. Maximovitch, Electrochim Acta 55 (2010) 3454.

[36] W. Wilhelmsen, T. Arnesen, Ø. Hasvold, N.J. Størkersen, Electrochim. Acta 36 (1991) 79.

[37] J. Hunter, The anodic behaviour of aluminium alloys in alkaline electrolytes, PhD thesis, University of Oxford, 1989.

[38] S. Adhikari, J. Lee, K.R. Hebert, J. Electrochem. Soc. 155 (2008) C16.

[39] S. Adhikari, K.R. Hebert, J. Electrochem. Soc. 155 (2008) C189.

[40] X.Y. Wang, J.M. Wang, Q.L. Wang, H.B. Shao, J.Q. Zhang, Mater. Corros. 61 (2010) 1.

[41] P.R. Birkin, M. Nestoridi, D. Pletcher, Electrochim. Acta 54 (2009) 6668

[42] R.P. Hamlen, T.J. Zoltner, W. Kobasz, M.V. Rose, Battery powered light source. United States Patent 4,745,529, May 17, 1988.

[43] D.M. Drazic, A.R. Despic, S. Zecevic, M. Atanackovic, I. Iliev, Power Sources 7 (1976) 353.

[44] E. Budevski, I. Iliev, A. Kaisheva, A. Despić, K. Krsmanović, J. Appl. Electrochem. 19 (1989) 323.

[45] H.G. Bin, G. Liang, Rare Metals 25 (2006) 360.

[46] B. Graver, A.T.J.v. Helvoort, K. Nisancioglu, Corros. Sci. 52 (2010) 377.

[47] Anawati, M.P. Halvorsen, K. Nisancioglu, J. Electrochem. Soc. 159 (2012) C211.

[48] I. Smoljko, S. Gudic, N. Kuzmanic, M. Kliskic, J. Appl. Electrochem. 42 (2012) 969

[49] S. Gudic, I. Smoljko, M. Kliskic, Mater. Chem. Phys. 121 (2010) 561

[50] J.A. Hunter, G.M. Scamans, W.B. O'Callaghan, P.A. Wycliffe, Aluminium batteries. United States Patent 5,004,654, 2 April 1991

[51] S. Müller, F. Holzer, J. Desilvestro, O. Haas, J. Appl. Electrochem. 26(1996) 1217.

[52] M. Rota, C. Comninellis, S. Moller, F. Holzer, O. Haas, J. Appl. Electrochem. 25 (1995) 114.

[53] F. Holzer, S. Müller, J. Desilvestro, O. Haas, J. Appl. Electrochem. 23 (1993) 125.

[54] K.-L. Hsueh, E.R. Gonzalez, S. Srinivasan, Electrochim. Acta 28 (1983) 691

[55] M.A. Streicher, J. Electrochem. Soc. 96 (1949) 170.

[56] D.M. See, R.E. White, J. Chem. Eng. Data 42 (1997) 1266

[57] W. Jin, H. Du, S. Zheng, H. Xu, Y. Zhang, J. Phys. Chem. B 114 (2010) 6542.

[58] A.C.C. Tseung, R.L. Quarshie, Z.G. Lin, Batteries having an aqueous alkaline electrolyte. World Intellectual Property Organisation Patent WO 88/ 01103, 1988. 
[59] B.N. Walters, A study of the anodic behaviour of aluminium alloys in alkaline electrolytes, PhD thesis, City University, 1988.

[60] G. Scamans, Chem. Ind. (1986) 192.

[61] M.L. Doche, F. Novel-Cattin, R. Durand, J.J. Rameau, J. Power Sources 65 (1997) 197.

[62] M.J. Niksa, A.J. Niksa, Primary aluminium-air battery. United States Patent, May 15, 1990

[63] E.J. Rudd, D.W. Gibbons, J. Power Sources 47 (1994) 329.

[64] J.A. Hunter, G.M. Scamans, W.B. O'Callaghan, Aluminium batteries. United States Patent 4,942,100, 17 July, 1990.

[65] M. Nestoridi, D. Pletcher, J.A. Wharton, R.J.K. Wood, J. Power Sources 193 (2009) 895.

[66] S. Feliu, M.J. Bartolomé, Surf. Interf. Anal. 39 (2007) 304.

[67] R.S.M. Patnaik, S. Ganesh, G. Ashok, M. Ganesan, V. Kapali, J. Power Sources 50 (1994) 331.

[68] E. Ghali, Corrosion Resistance of Aluminium and Magnesium Alloys. Understanding, Performance and Testing, Wiley, 2010.

[69] A.A. Mazhar, S.T. Arab, E.A. Noor, Bull. Electrochem. 17 (2001) 449.

[70] I.J. Albert, M.A. Kulandainathan, M. Ganesan, V. Kapali, J. Appl. Electrochem. 19 (1989) 547

[71] B. Roald, M.A. Streicher, J. Electrochem. Soc. 97 (1950) 283.

[72] J.A. Hunter, Aluminium batteries. European Patent 0326338 A2, 1989.

[73] G. Scamans, B. O'Callaghan, R. Hamlen, N. Fitzpatrick, Power Sources 11 (1986) 267.

[74] G.M. Scamans, W.B. O'Callaghan, N.P. Fitzpatrick, R.P. Hamlen, in: 21st Intersociety Energy Conversion Conference, American Chemical Society, San Diego, 1986, pp. 1057-1061.

[75] P.W. Jeffrey, W. Halliop, F.N. Smith, Aluminium anode alloy. United States Patent 4,751,086, 14 June 1988.

[76] C.D.S. Tuck, J.A. Hunter, G.M. Scamans, J. Electrochem. Soc. 134 (1987) 2970.

77] H. Baker, ASM Handbook, in: Alloy Phase Diagrams, vol. 3, ASM International, 1992.

[78] K.R.V. Horn, Aluminium, in: Properties, Physical Metallurgy and Phase Diagrams, vol. 1, American Society for Metals, 1967.

[79] D.D. MacDonald, S. Real, M. Urquidi-Macdonald, J. Electrochem. Soc. 135 (1988) 2397.

[80] M.C. Reboul, P.H. Gimenez, J.J. Rameau, Corros. NACE 40 (1984).

[81] K.-K. Lee, K.-B. Kim, Corros. Sci. 43 (2001) 561.

[82] K. Nisancioglu, L. Odden, in: Proceedings of the Second Symposium on Electrode Materials and Processes for Energy Conversion and Storage, The Electrochemical Society, 1987, pp. 499-512.

[83] D.D. MacDonald, Electrochim. Acta 56 (2011) 1761

[84] J.T. Ziebarth, J.M. Woodall, R.A. Kramer, G. Choi, Int. J. Hydrogen Energy 36 (2011) 5271.

[85] H.W. Sheng, K. Lu, E. Ma, Acta Mater. 46 (1998) 5195.

[86] A.S. Mideen, M. Ganesan, M. Anbukulandainathan, K.B. Sarangapani, V. Balaramachandran, V. Kapali, S.V. Iyer, J. Power Sources 27 (1987) 235.

[87] M. Paramasivam, M.Jayachandran, S.V. Iyer, J. Appl. Electrochem. 33(2003) 303.

[88] M. Paramasivam, S.V. Iyer, J. Appl. Electrochem. 31 (2001) 115.

[89] M. Paramasivam, G. Suresh, B. Muthuramalingam, S.V. Iyer, V. Kapali, J. Appl. Electrochem. 21 (1991) 452.

[90] S.Z.E. Abedin, A.O. Saleh, J. Appl. Electrochem. 34 (2004) 331.

[91] D.J. McPhail, The anodic behaviour of aluminium alloys in alkaline solutions, PhD thesis, University of Canterbury, 1993.

[92] D.D. MacDonald, K.H. Lee, A. Moccari, D. Harrington, Corros. Sci. 44 (1988) 652.

[93] T. Tang, L. Lu, H.W. Roesky, L. Wang, B. Huang, J. Power Sources 138 (2004) 313.

[94] Y. Zhang, Y.-S. Song, Y.-S. Wang, J. Shanghai Univ. 11 (2007) 426.

[95] M. Warmuzek, Metallographic techniques for aluminium and its alloys, in: ASM Handbook, Metallography and Microstructures, vol. 9, ASM, 2004.

[96] G.S. Frankel, J. Electrochem. Soc. 145 (1998) 2186.

[97] Z. Szklarska-Smialowska, Corros. Sci. 41 (1999) 1743.

[98] G. Scamans, J. Hunter, C. Tuck, in: Proceedings of the 16th International Power Sources Symposium 1988, Power Sources, vol. 12, 1988, p. 363.

[99] J.T.B. Gunderson, A. Aytac, J.H. Nordlien, K. Nisancioglu, Corros. Sci. 46 (2004) 697.

[100] W. Bohnstedt, J. Power Sources 5 (1980) 245.

[101] M.W. Dodson, Aluminium alloys for battery anodes in alkaline solutions, PhD thesis, University of Southampton, 1992.

[102] C.F.W. Norman, Corrosion of aluminium, PhD thesis, University of Southampton, 1986

[103] T.A. Dougherty, A.P. Karpinski, S.P. Lapp, R.N. Kallok, S.V. Natale, A.G. Cannone, in: 17th International Telecommunications Energy Conference, Hague, The Netherlands, 1995, pp. 821-827.

[104] K.D. Ralston, N. Birbilis, Corrosion 66 (2010) 0750051.

[105] L. Shu-quan, Z. Yong, G. Di-kai, T. Yan, M. Zhi-wei, Trans. Nonferrous Met. Soc. China 20 (2010) 942.

[106] Aluminium-air fuel cell becoming commercially viable, http://aluminum. $\operatorname{org} / \mathrm{AM} /$ Template.cfm?Section $=$ Home\&template $=/ \mathrm{CM} / \mathrm{HTMLDisplay}$ cfm\&ContentID $=15793$, (accessed 07.08.12).

[107] M.N. Moussa, M.M. El-Tagoury, A.A. Radi, S.M. Hassan, Anti-corrosion Meth. Mater. 37 (1990) 4.

[108] N.A.F. Al-Rawashdeh, A.K. Maayta, Anti-corrosion Meth. Mater. 52 (2005) 160.

[109] A.M. Abdel-Gaber, E. Khamis, H. Abo-Eldahab, S. Adeel, Mater. Chem. Phys. 124 (2010) 773.

[110] X.Y. Wang, J.M. Wang, H.B. Shao, J.Q. Zhang, C.N. Cao, J. Appl. Electrochem. 35 (2005) 213.
[111] V. Neburchilov, H. Wang, J.J. Martin, W. Qu, J. Power Sources 195 (2010) 1271.

[112] B. Wang, J. Power Sources 152 (2005) 1.

[113] S. Litser, G. McLean, J. Power Sources 130 (2004) 61.

[114] N. Fujiwara, M. Yao, Z. Siroma, H. Senoh, T. Ioroi, K. Yasuda, J. Power Sources 196 (2011) 808.

[115] J.J. Martin, V. Neburchilov, H. Wang, W. Qu, in: Electrical Power \& Energy Conference (EPEC), IEEE, 2009, p. 1.

[116] F. Cheng, Chem. Soc. Rev. 41 (2012) 2172.

[117] L. Jorissen, J. Power Sources 155 (2006) 23.

[118] J.S. Spendelow, A. Wieckowski, Phys. Chem. Chem. Phys. 9 (2007) 2654.

[119] F. Bidault, D.J.L. Brett, P.H. Middleton, N.P. Brandon, J. Power Sources 187 (2009) 39.

[120] Z.-Q. Fang, M. Hu, W.-X. Liu, Y.-R. Chen, Z.-Y. Li, G.-Y. Liu, Electrochim. Acta 51 (2006) 5654.

[121] A.L. Dicks, J. Power Sources 156 (2006) 128

[122] M. Watanabe, M. Tomikawa, S. Motoo, J. Electroanal. Chem. 195 (1985) 81.

[123] M. Maja, C. Orecchia, M. Strano, P. Tosco, M. Vanni, Electrochim. Acta 46 (2000) 423.

[124] K. Tomantschger, K.V. Kordesch, J. Power Sources 25 (1989) 195.

[125] S. Muller, K. Striebel, O. Haas, Electrochim. Acta 39 (1994) 1661.

[126] H. Gharibi, R.A. Mirzaie, J. Power Sources 115 (2003) 194

[127] T. Poux, F.S. Napolskiy, T. Dintzer, G. Kéranguéven, S.Y. Istomin, G.A. Tsirlina, E.V. Antipov, E.R. Savinova, Catalytic Mater. Energy Past, Present Future 1 (2012) 83.

[128] S. Muller, F. Holzer, H. Arai, O. Haas, J. New Mater. Electrochem. Sys. 2 (1999) 227.

[129] X.-H. Yang, Y.-Y. Xia, J. Solid State Electrochem. 14 (2010) 109.

[130] Y. Kiros, T. Quatrano, P. Bjornbom, Electrochem. Commun. 6 (2004) 526

[131] M. Hayashi, H. Uemura, K. Shimanoe, N. Miura, N. Yamazoe, Electrochem. Solid-State Lett. 1 (1998) 268.

[132] Y. Kiros, Oxygen reduction electrode. Patent WO 02/075827 A1, 2002.

[133] Y. Kiros, S. Schwartz, J. Power Sources 36 (1991) 547.

[134] S.L.j. Gojkovic, S. Gupta, R.F. Savinell, J. Electroanal. Chem. 462 (1999) 63.

[135] N. Cheng, C. Kemna, S. Goubert-Renaudin, A. Wieckowski, Electrocatalysis 3 (2012) 238.

[136] A.L. Zhu, H. Wang, W. Qu, X. Li, Z. Jong, H. Li, J. Power Sources 195 (2010) 5587.

[137] F. Cheng, J. Shen, W. Ji, Z. Tao, J. Chen, Appl. Mater. Interf. 1 (2009) 460.

[138] S.C.S. Lai, M.T.M. Koper, Phys. Chem. Chem. Phys. 11 (2009) 10446.

[139] C.N. Chervin, J.W. Long, N.L. Brandell, J.M. Wallace, N.W. Kucko, D.R. Rolison, J. Power Sources 207 (2012) 191

[140] F. Bidault, D.J.L. Brett, P.H. Middleton, N. Abson, N.P. Brandon, Int. J. Hydrogen Energy 34 (2009) 6799.

[141] A. Kloke, F.v. Stetten, R. Zengerle, S. Kerzenmacher, Adv. Mater. 23 (2011) 4976

[142] B.G. Pollet, E.F. Valzer, O.J. Curnick, Int. J. Hydrogen Energy 36 (2011) 6248.

[143] D. Zhang, T. Sotomura, T. Ohsaka, Chem. Lett. 35 (2006) 520.

[144] M.S. El-Deab, S.H. Othman, T. Okajima, T. Ohsaka, J. Appl. Electrochem. 38 (2008) 1445

[145] M.S. El-Deab, T. Ohsaka, Surf. Chem. 45 (2006) 5963.

[146] A. Mukherjee, I.N. Basumallick, J. Power Sources 45 (1993) 243

[147] S. Guerin, B.E. Hayden, D. Pletcher, M.E. Rendall, J.-P. Suchsland, J. Comb. Chem. 8 (2006) 679.

[148] S. Guerin, B.E. Hayden, J. Comb. Chem. 8 (2006) 66.

[149] R. Jiang, D. Chu, Rev. Sci. Instrum. 76 (2005) 062213.

[150] R. Jiang, Rev. Sci. Instrum. 78 (2007) 072209-072211.

[151] A.D. Kay, Novel Aluminium Air Batteries for Ultralight Micro-aircraft Master of Philosophy, University of Southampton, 2005.

[152] www.m-pore.de, (accessed 07.08.12).

[153] Aluminium metal foam suppliers list, http://www.metalfoam.net/, (accessed 07.08.12).

[154] H. Salavagione, R. Prieto, E. Morallón, J. Narciso, J. Appl. Electrochem. 40 (2010) 241.

[155] R. Goodall, A. Mortensen, Adv. Eng. Mater. 9 (2007) 951.

[156] C. Li, W. Ji, J. Chen, Z. Tao, Chem. Mater. 19 (2007) 5812.

[157] N.A. Popovich, R. Govind, J. Power Sources 112 (2002) 36

[158] W.A. Ferrando, J. Power Sources 130 (2004) 309.

[159] A.A. Mohamad, Corros. Sci. 50 (2008) 3475.

[160] G.M. Wu, S.J. Lin, C.C. Yang, J. Membr. Sci. 280 (2006) 802.

[161] J.M. Wang, J.B. Wang, H.B. Shao, X.X. Zeng, J.Q. Zhang, C.N. Cao, Mater. Corros. 60 (2009) 977

[162] J.-B. Wang, J.-M. Wang, H.-B. Shao, J.-Q. Zhang, C.-N. Cao, J. Appl. Electrochem. 37 (2007) 753.

[163] B.A. Abd-el-Nabey, N. Khalil, E. Khamis, Surf. Technol. 22 (1984) 367.

[164] H.B. Shao, J.M. Wang, X.Y. Wang, J.Q. Zhang, C.N. Cao, Electrochem. Commun. 6 (2004) 6.

[165] A. Mukherjee, I.N. Basumallick, J. Power Sources 58 (1996) 183.

[166] H. Meng, P.K. Shen, Electrochem. Commun. 8 (2006) 588

[167] N. Kishimoto, T. Fukutsuka, Y. Uchimoto, T. Abe, Z. Ogumi, M. Inaba, A. Tasaka, in: ECS Meeting Abstracts, Honolulu, HI, 2008, p. 571

[168] S.Z.E. Abedin, E.M. Moustafa, R. Hempelmann, H. Natter, F. Endres, Electrochem. Commun. 7 (2005) 1111

[169] N.V. Plechkova, K.R. Seddon, Chem. Soc. Rev. 37 (2008) 123.

[170] M. Armand, F. Endres, D.R. MacFarlane, H. Ohno, B. Scrosati, Nat. Mater. 8 (2009) 621. 
[171] F. Endres, A.P. Abbott, D.R. MacFarlane, Electrodeposition from Ionic Liquids, Wiley-VCH, 2008

[172] W. Simka, D. Puszczyk, G. Nawrat, Electrochim. Acta 54 (2009) 5307.

[173] Betting on a metal-air battery breakthrough, http://www.technologyreview. com/energy/23877/page1/, (accessed 07.08.12).

[174] S. Licht, G. Levitin, R. Tel-Vered, C. Yarnitzky, Electrochem. Commun. 2 (2000) 329.

[175] E.M. Moustafa, S.Z.E. Abedin, A. Shkurankov, E. Zschippang, A.Y. Saad, A. Bund, F. Endres, J. Phys. Chem. B 111 (2007) 4693.

[176] F. Endres, S.Z.E. Abedin, Phys. Chem. Chem. Phys. 8 (2006) 2101

[177] A.P. Abbott, F. Qiu, H.M.A. Abood, M.R. Ali, K.S. Ryder, Phys. Chem. Chem. Phys. 12 (2010) 1862

[178] N.D. Ingale, J.W. Gallaway, D. Steingart, S. Khatun, P.J. Sideris, S.G. Greenbaum, S. Banerjee, A. Couzis, in: 219th ECS Meeting, Montreal, QC, Canada, 2011.

[179] T. Jiang, M.J.C. Brym, G. Dubé, A. Lasia, G.M. Brisard, Surf. Coat. Technol. 201 (2006) 1 .

[180] Y. Zhao, T.J. VanderNoot, Electrochim. Acta 42 (1997) 3.

[181] Y. Zhao, T.J. VanderNoot, Electrochim. Acta 42 (1997) 1639.

[182] J. Zhang, J. Electrochem. Soc. 157 (2010) A940.

[183] T. Kuboki, T. Okuyama, T. Ohsaki, N. Takami, J. Power Sources 146 (2005) 766.

[184] M. Morimitsu, in: ECS Meeting Abstracts, ECS, Chicago, Illinois, 2007, p. 409.

$185]$ D.S. Silvester, R. Compton, Z. Phys. Chem. 220 (2006) 1247.

[186] S. Ernst, L. Aldous, R.G. Compton, J. Electroanal. Chem. 663 (2011) 108

[187] J.O.M. Bockris, B.E. Conway, E. Yeager, R.E. White, Comprehensive Treatise of Electrochemistry, in: Electrochemical Processing, vol. 2, Plenum Press, 1981.

[188] C.A. Hampel, The Encyclopedia of Electrochemistry, Reinhold Publishing Corporation, 1964.

[189] P.W. Jeffrey, W. Halliop, F.N. Smith, Aluminium anode alloy. European Patent 0,209,402, 1987.

[190] G.P. Tarcy, R.M. Mazgaj, Aluminium alloy and associated anode. United States Patent 4,808,498, 28 Feb., 1989.

[191] M. Yuasa, G. Sakai, K. Shimanoe, Y. Teraoka, N. Yamazoe, J. Electrochem. Soc. 151 (2004) A1690.
[192] Y. Shimizu, K. Uemura, H. Matsuda, N. Miura, N. Yamazoe, J. Electrochem. Soc. 137 (1990) 3430.

[193] M. Bursell, M. Pirjamali, Y. Kiros, Electrochim. Acta 47 (2002) 1651.

[194] M. Hayashi, H. Uemura, K. Shimanoe, N. Miura, N. Yamazoe, J. Electrochem. Soc. 151 (2004) A158.

[195] J.P. Lukaszewicz, S. Imaizumi, M. Yuasa, K. Shimanoe, N. Yamazoe, J. Mater Sci. 41 (2006).

[196] L. Guangchuan, L. Shuguang, L. Changlong, O. Xiuqin, J. Rare Earths 25 (2007) 264.

[197] M. Yuasa, K. Shimanoe, Y. Teraoka, N. Yamazoe, Electrochem. Solid-State Lett. 14 (2011) A67.

[198] J. Lamminen, J. Kivisaari, M.J. Lampinen, M. Viitanen, J. Vuorisalo, J. Electrochem. Soc. 138 (1991) 905.

[199] N. Li, X. Yan, W. Zhang, B. Lin, J. Power Sources 74 (1998) 255.

[200] N. Li, X. Yan, Y. Jin, S. Li, B. Lin, J. Appl. Electrochem. 29 (1999) 1351.

[201] T. Nissinen, T. Valo, M. Gasik, J. Rantaneu, M. Lampinen, J. Power Sources 106 (2002) 109.

202] S. Zaromb, J. Electrochem. Soc. 109 (1962) 1125.

[203] J.T. Reding, J.J. Newport, Mater. Prot. 5 (1966) 15.

[204] J.F. Cooper, R.V. Homsey, J.H. Landrum, in: 15th Intersociety Energy Conversion Engineering Conference, vol. 2, 1980, p. 1487.

[205] T. Valand, O. Mollesad, G. Nilsson, in: Proceedings of the 12th International Power Sources Symposium, Power Sources, vol. 8, 1980, p. 523.

[206] New Scientist, 1987, p. 31.

[207] K. Cameron, V. Kowalenko, Portable Unmanned Aircraft System Concept Investigation, Defence Science and Technology Organisation Aeronautical and Maritime Research Laboratory, Australia, 1995, DSTO-TR-0210, http:/ dspace.dsto.defence.gov.au/dspace/handle/1947/4266.

[208] New Scientist, 1987, p. 38

[209] R.J. Coin, C.W.B. Jr., J.M. Noscal, Metal hydroxide crystalliser and filter. United States Patent 4,994,332, Feb 19, 1991.

[210] G.M. Scamans, S.P. Lapp, S.M. Warner, D. Holmes, in: Telecommunications Energy Conference, INTELEC '92, 14th International, Washington, DC, USA, 1992, pp. 413-417.

[211] J.A. Hunter, Aluminium batteries. United States Patent 5,032,474, 16 July 1991. 